\title{
A RECRIAÇÃO CONSERVADORA DO ESTADO: IMPASSES NO REFORMISMO PROGRESSISTA E POPULAR E O GOLPE DE 2016
}

\author{
THE STATE CONSERVATIVE REBUILD: IMPASSESIN THE PROGRESSIST \\ AND POPULAR REFORMISM AND THE 2016 COUP D`ÉTAT
}

\section{LA RECONSTRUCCIÓN CONSERVADORA DEL ESTADO: IMPASSES EN EL REFORMISMO PROGRESISTA Y POPULAR Y EL GOLPE DE 2016}

\section{Alexis Toríbio Dantas}

Pós-doutorado em Estudos Latino-Americanos pela Universidade de Varsóvia. Doutorado em Economia Industrial e da Tecnologia pelo Instituto de Economia da Universidade Federal do Rio de Janeiro (IEUFRJ). Professor Associado da Faculdade de Ciências Econômicas da Universidade do Estado do Rio de Janeiro (FCE-UERJ). Universidade do Estado do Rio de Janeiro - Campus Maracanã. Rua São Francisco Xavier, 524. Rio de Janeiro, RJ.Email: alexis.dantas@gmail.com

\section{Elias Marco Khalil Jabbour}

Doutorado em Geografia Humana pela Faculdade de Filosofia, Letras e Ciências Humanas da Universidade de São Paulo (FFLCH-USP). Professor Adjunto na Área de Economia e Política do Planejamento Econômico da Faculdade de Ciências Econômicas da Universidade do Estado do Rio de Janeiro (FCE-UERJ). Universidade do Estado do Rio de Janeiro - Campus Maracanã. Rua São Francisco Xavier, 524. Rio de Janeiro, RJ.Email: eliasjabbour@terra.com.br

\section{Bruno Leonardo Barth Sobral}

Doutorado em Desenvolvimento Econômico pelo Instituto de Economia da Universidade Estadual de Campinas (IE-UNICAMP). Professor Adjunto na Área de Economia Regional e Urbana da Faculdade de Ciências Econômicas da Universidade do Estado do Rio de Janeiro (FCE-UERJ). Universidade do Estado do Rio de Janeiro - Campus Maracanã. Rua São Francisco Xavier, 524. Rio de Janeiro, RJ. Email:brunoleo.rj@hotmail.com

\section{RESUMO}

O objetivo deste artigo é demonstrar que a crise política brasileira, que culminou no impeachment da presidente da república Dilma Roussef, antes de ser fruto de uma profunda crise econômica tem causa na formação de um amplo condomínio empresarial, partidário e midiático com tentáculos no seio do aparelho do Estado. A formação deste condomínio político de caráter conservador foi parte de um processo de acúmulo de forças por causa de riscos na transição do neoliberalismo a um Novo Projeto Nacional Brasileiro. Como os péssimos resultados de 2015 foram criticados não por seus equívocos decisórios e sim por falta de confiança na política econômica, buscou-se as condições objetivas para deliberar um golpismo de caráter explícito. Sob a aparência de estabilidade e respeito às leis, oculta que se propõem a recriar o Estado impondo duras restrições a sua discricionariedade.

PALAVRAS-CHAVE: Economia Política; Crise Política; Golpe de Estado. 


\begin{abstract}
The aim of this paper is to demonstrate that the Brazilian political crisis that culminated in the impeachment of President Dilma Roussef, is not a direct result of the economic crisis, but a consequence of a broad coalition involving business groups, opposition parties and media with influence in the heart of the state apparatus. The formation of this conservative character of political coalition was part of a process to accumulation of forces because risks in the transition from neoliberalism to a New Brazilian National Project. As the terrible results of 2015 were criticized not for their decision-making mistakes but for lack of confidence in economic policy, the objective conditions was given to deliberate an explicit character coup. Under the guise of stability and respect for laws, it hides that they set out to recreate the state imposing harsh restrictions on their discretionary power.
\end{abstract}

KEYWORDS: Political Economy; Political Crisis; Coup d'Etat.

\title{
RESUMEN
}

El propósito de este artículo es demostrar que la crisis política brasileña, que culminó con la destitución del Presidente de la República Dilma Roussef, antes de ser resultado de una profunda crisis económica, fue consequencia de la formación de una comunidad entre los empresarios, partidos politicos y los medios de comunicación con tentaculos en el seno del aparato estatal. La formación de este condominio politico de carácter conservador fue parte de un proceso de acumulación de fuerzas debido a los riesgos en la transición del neoliberalismo a un nuevo proyecto nacional brasileño. A medida que se han criticado los malos resultados de 2015 para su decisión de no errores, pero por la falta de confianza en la política económica, hemos tratado las condiciones objetivas para resolver un golpe de carácter explícito. Bajo la apariencia de estabilidad y el respeto de la ley, oculta que pretenden recrear el estado imponiendo fuertes restricciones en su discreción.

PALABRAS-CLAVE: Economia Política; Crisis Política; Golpe de Estado

\footnotetext{
"Nessas circunstâncias, o consenso teria que ser substituído seja por uma forma de totalitarismo - unificação do poder nas mãos de um grupo autodesignado para definir as prioridades da ação do Estado - seja pela fragmentação do sistema de decisões, forma de "feudalismo", ou senhorio, que opera sem unidade de propósito" (CELSO FURTADO, 1983, p.73-74).
}

a 


\section{INTRODUÇÃO}

\section{DA CRISE INSTITUCIONAL AO IMPULSO DE RECRIAÇÃO DO ESTADO}

O ano de 2016 é uma inflexão no processo de redemocratização brasileiro. Demarca a concretização de novo golpe de Estado que apresenta similaridades e diferenças com o golpe de 1964. Sua principal similaridade é o denuncismo seletivo de uma corrupção sistêmica do Estado como ideia-força para articular grande imprensa, setores moralistas de classe média e interventores da ordem constitucional. Antes que o desdobramento de um debate sobre a maior capacidade de consolidação de metas estratégicas e estruturantes como: aprofundamento de um Estado de Bem-Estar social ou retomada de um Estado Desenvolvimentista, o que transcorreu foi uma crítica sobre um suposto inchaço e aparelhamento do mesmo. Como contraponto, surgiu a idealização de um processo de ruptura institucional que daria ganhos de racionalidade e de moralidade. O apelo salvacionista de "passar a limpo" o país e refundá-lo de um marco zero permitiu um suposto governo de "pacificação nacional"ser visto como a solução.

Contudo, diferentemente de 1964, não coube ainda aos militares assumir o protagonismo como "guardiões da ordem" (apesar do desejo de alguns grupos mais extremistas). A própria experiência histórica anterior já demonstrou o risco de uma via militar fugir do controle e almejar se perpetuar no poder. Nesse sentido, o golpe atual não se auto-intitula uma "revolução" como aquele de 1964. Isso não significa que suas aspirações e seus efeitos são modestos, ao contrário, significa maior cuidado para sustentar uma aparência de normalidade democrática e cumprir o objetivo maior: um antiestatismo de viés entreguista (ou seja, antinacional) e que desarticule a relação entre a valorização do serviço público e as conquistas sociais. O aspecto mais perverso da via golpista atual é defender que nem houve uma crise institucional, tão somente sendo aplicados os dispositivos constitucionais. Sob a aparência de estabilidade e respeito às leis, oculta que se propõem a recriar o Estado impondo duras restrições a sua discricionariedade.

Sob a aparência de um justo combate à corrupção, ganha enorme força uma onda de doutrinação conservadora que reacende uma nova instância de moderação autoritária supostamente neutra e "acima" da política e dos partidos: os próprios órgãos de controle do governo e judiciário criados pela constituição. Argumentos pseudo-jurídicos dão a senha para aspectos extrajurídicos desencadearem todo tipo de interesse de ocasião e instrumentalizar um apelo emocional que autorizasse um poder tutelar. Esse poder tutelar terá o salvo-conduto para impor a população um severo ajuste que reacomode o controle concentrado da riqueza nacional, imponha sua subordinação externa e arregimente a passividade da população. 
Paradoxalmente, a crítica conservadora da confusão do interesse público com o interesse privado que ensejaria à corrupção, invoca como solução uma redução do Estado e um maior "privatismo" da gestão pública. O principal resultado prático é ensejar uma recriação do Estado sob o pressuposto ideológico de que este deve "dar espaço" para a iniciativa privada e ele se tornar tão eficiente quanto uma empresa privada, e isso será visto como "eficiência democrática" (TEMER, 2013). Por essa razão a segunda seção discutirá algumas considerações teórico-estratégicas, em especial, fazendo a crítica do uso das noções de patrimonialismo e populismo como bases de um mito sobre os limites da formação do Estado nacional.

A partir disso, será feita a reinterpretação do Lulismo na terceira seção. Como fenômeno complexo de coalizão de classes, será discutida sua necessidade histórica. Nesse sentido, buscará questionar o espantalho criado por seus opositores, e serão apontadas algumas de suas fragilidades fundamentais. Nesses termos, o Lulismo será avaliado como a sustentação de uma maioria política heterogênea voltada para uma ruptura em meio à continuidade. Diante dessa tese, antes que aceitar o pré-julgamento vago como um projeto espúrio de poder (corrompido), serão discutidos os impasses para a execução de seu reformismo progressista e popular em meio a uma sociedade conservadora.

A quarta seção chamará a atenção para a centralidade da dimensão econômica. Antes que uma rendição ao economicismo, o que será tratado é como, ao contrário do senso comum, a crise econômica é decorrência de uma crise política que mina a possibilidade de execução programática para um Novo Projeto Nacional. Assim, a via golpista só possível de ser confirmada com a recriação do Estado por uma "ditadura da maioria" travestida de condutora de uma "eficiência democrática", sustentada por uma visão etapista vulgar que julga que o reformismo progressista e popular do Lulismo já foi até seu limite e deve ser superado (quando, alterando as prioridades, tenta conferir ao retrocesso uma aparência de evolução).

\section{A ECONOMIA POLÍTICA DO ESTADO BRASILEIRO: CONSIDERAÇÕES CRÍTICAS SOBRE AS NOÇÕES DE PATRIMONIALISMO E POPULISMO}

O golpe de 2016 marca um processo de negação da grande política. Coutinho (2010) retoma Gramsci para discutir que a grande política se refere à disputa por diferentes propostas de sociedade na qual se manifesta uma clara luta de classes, enquanto a pequena política é a disputa dentro da classe dominante considerando a continuidade do modelo de sociedade já existente. Logo, só há possibilidade de uma estratégia revolucionária com ideologias orgânicas quando há o reconhecimento do papel ativo da grande política para a construção de "grandes narrativas" sob um ponto de vista da totalidade histórica. 
Um ato terminal da grande política é o processo de negar-se e resumir tudo a hegemonia da pequena política, estruturando assim um consentimento passivo que assegura a reprodução do status quo independente de realizar sua defesa articulada. Basta "naturalizar" as relações sociais e a forma de representação de classes, ocultando que a dinâmica da história é feita de tensões e utilização do dissenso como forma legítima de conquista de direitos. A hegemonia da pequena política depende de resumir tudo a mera disputa de projetos de poder tendo como critério tecnicidades sobre a gestão e administração da coisa pública, ou seja, como se as facções em disputa não divergissem essencialmente no conteúdo de suas propostas.

Sob essa hegemonia da pequena política, não se vai muito além do senso comum ao se tratar de concepções de mundo, marcando-se pela falta de estímulos para a tomada de consciência mais profunda da realidade. Essa orientação se reforça sobre visões que atestam o fim das ideologias e contestam que ainda existem diferenças profundas entre posições de direta e de esquerda. A democracia passa a ser vista independente dos interesses de classe, como se fosse a conservação de crenças e valores estáveis sobre parâmetros de racionalidade e moralidade. Nessa lógica, inclusive se generaliza a ideia que não existem resultados positivos sem sacrifícios sociais, devendo-se proteger as instituições republicanas do risco de "excessos de demanda" da população.

Esse processo só é possível ao se encobrir a luta de classes por um diagnóstico assumido arbitrariamente como senso comum: uma oposição entre mercado e Estado. Essa oposição dá margem ao repúdio acrítico do papel do Estado, ocultando que suas atribuições são a garantia da soberania nacional e da proteção social, o que significa que não é neutro diante de interesses de classe. Todavia, é um equívoco assumir um viés determinístico ao considerar a não neutralidade, como se o Estado estivesse associado de forma automática e permissiva com grandes interesses constituídos. Esse viés determinístico está presente nas visões que colocam a problemática do patrimonialismo como algo resumido a coisa pública, e condena qualquer processo reformista como populismo por uma suposta manipulação social (viés da direita) ou ausência de perspectiva revolucionária insurgente (viés do esquerdismo radical). Ou seja, ergue-se um espantalho: há uma ampla burocratização geradora de um binômio corrupção/ineficiência baseada em uma tara estatizante, campo fértil às posturas personalistas (com risco totalitário) e ao compadrio fisiológico.

O economicismo superficial dá fundamento a isso a partir da teoria do rent-seeking (Krueger, 1974) pela qual se atesta a captura do interesse público por grandes empresários, levando a inchamento da máquina pública para acomodar todos os privilégios de classe. $\mathrm{O}$ pressuposto fundamental é que se trata de aumento da participação na renda agregada já 
existente e não leva a geração de renda nova significativa, logo, assume um caráter predatório (com claras brechas à corrupção institucionalizada). Diante disso, essa teoria defende que seria preciso pensar muito bem as prioridades políticas a partir das restrições fiscais que estão postas. Logo, uma das principais sugestões é a busca de uma estrutura enxuta, que destrave a concorrência capitalista e elimine ineficiências e gastos/isenções fiscais supostamente injustificáveis para focar nas áreas que seriam vistas como prioritárias ao interesse público. Seu componente ideológico leva a conclusão que o papel do governo deveria ser basicamente de garantir um ambiente favorável aos negócios e, eventualmente, corrigir falhas de mercado.

A proposta toma como referência uma forma de indicador-sintético no qual as oportunidades para as atividades de rent-seeking crescem com o aumento da ação estatal, em particular, com iniciativas discricionárias no campo econômico (algo visto como "intervencionismo"). Dessa forma, o problema público se resumiria a uma verificação de ineficiência alocativa, que retoricamente é tratada como irresponsabilidade fiscal por levar a um custeio governamental que se reverte em uma pesada carga tributária. Essa construção teórica se traduz em senso comum quando respalda um argumento moral: decisões baseadas em critérios políticos levam aos contribuintes de todo o país pagarem por um benefício a serem gozados por poucos, grandes grupos ligados ao governo, e ainda ser socializando seus prejuízos pela eminência de gerar uma crise fiscal.

Portanto, o grande mal seria a política que impede a segurança jurídica dos contratos e a defesa da concorrência, permitindo a sobrevivência de agentes ineficientes e, assim, inibindo a produtividade e as possibilidades de maiores ganhos de bem-estar social. A conclusão fundamental é que deveria ser contido um viés estatizante dado que o setor público seria menos produtivo que a iniciativa privada e mais exposto a desvios de conduta.

A sociologia também ancorou o "espantalho" da ampla burocratização quando buscou justificar uma perversão institucional por uma suposta permanência de uma excepcionalidade cultural e social pré-moderna no Brasil. Essa perversão oficializaria relações de favor enquanto fundamento da ordem socioeconômica, "viciando" toda a sociedade ao mantê-la dependente da vontade da autoridade política. Inicialmente, essa posição derivada de visões eurocêntricas dadas do século XIX que atestavam a impossibilidade de civilização nos trópicos pautada em uma filosofia da história repleta de determinismos geográficos e raciais. Dessa forma, o Brasil estaria condenado ao atraso por culpa de suas riquezas naturais não exigirem maior esforço e ter um povo de comportamento preguiçoso, logo, acostumado à vadiagem e complacente com desvio de caráter.

O contrapondo seria a civilização européia (e também norte-americana). Sob essa 
vertente se nota como o apelo a meritocracia pode esconder na essência um "complexo de inferioridade" com nossa matriz formativa vista como moralmente inferior. Em particular, o ocultamento do estatuto da escravidão e de um processo de acumulação primitiva/espoliativa e, no seu lugar, atribuir o atraso a uma miscigenação étnica e a uma "maldição dos recursos naturais" (curiosamente, esse último ponto reeditado recentemente a respeito do petróleo e a exploração do pré-sal).

A resposta nacional veio com Gilberto Freyre (2005) que constrói um vínculo afetivo e emocional entre os brasileiros através de um mito identitário: a mestiçagem seria nosso trunfo, marcado por virtudes como a festividade e capacidade de superação de adversidades. Ao invés de complexo de inferioridade, o orgulho do povo sedimenta a autoestima compartilhada, base fundamental para um projeto nacional marcado pela utopia de uma civilização tolerante ${ }^{1}$.

Como mito identitário, trata-se de uma referência para soldar um pacto social, inventando uma pré-modernidade que teria algum grau de virtude. Especificamente, permite um consenso sobre a sagacidade e a criatividade de seu povo, apesar das resistências de uma sociedade conservadora preocupada em manter privilégios de classe, logo, reproduzir-se altamente desigual. Apropriando-se disso, o Varguismo impulsiona um processo de modernização através de uma estratégia de industrialização que foi capaz de um feito único, combinar uma poderosa máquina de crescimento econômico com uma igualmente poderosa máquina de desigualdade.

Direitos foram parcialmente concedidos e a maior parte dos conflitos foram escamoteados por um processo de "fuga para frente" que garantia formas de acomodação social com o progresso material, ainda que se agudizasse suas contradições em diversos aspectos: acesso à terra urbana e à terra rural, à educação e à saúde de qualidade, à moradia e aos serviços coletivos (segurança, transporte, saneamento etc.), à inserção no mercado de trabalho formal e seguridade social. O fato é que se incorporou grandes massas populacionais e porções do território em um projeto nacional ainda que recriando/ampliando traços de atraso socioeconômico. Afinal, estruturas de dominação toleram a criação das bases de uma sociedade de consumo de massas, mas travaram a prioridade política para que os direitos sociais fossem mais ampliados e plenamente assegurados.

Sendo notável o peso de uma herança de relações sociais escravocratas e de formas de acumulação primitiva/espoliativa para os limites da modernização, a crítica à Freyre se voltou basicamente para outra direção: a herança ibérica do Estado. Sérgio Buarque de

Seu contraponto é barbárie armamentista e xenófoba, geradora de guerras mundiais e uma série de conflitos armados ao redor do mundo. 
Holanda (1999) inverte o diagnóstico positivo voltado à produção de solidariedade nacional, e, em sua noção de cordialidade, oculta o comportamento de classe e personifica um tipo social pouco racionalista e bastante particularista que confere privilégios sob uma organização social de leis rígidas para aqueles não próximos do poder. E mais, essa distorção se devia aos imperativos de uma tradição institucional que seriam internalizados na cultura popular que valoriza o "jeitinho".

Essa crítica é reforçada por Raymundo Faoro (2001) que destacou o estamento burocrático como uma elite que se apropria da coisa pública a fim de perpetuar seus privilégios que são em sua origem aristocráticos. E mais, ao manter a confusão entre o interesse público com o interesse privado, fragiliza o funcionamento de um livre mercado idealizado e visto como sinônimo de capitalismo. Assim, oculta-se que, ao invés de existir uma burocracia estruturada plenamente e refletida em uma forte estrutura de planejamento e coordenação estatal, prevaleceu na maior parte do tempo e na maioria das regiões um privatismo da coisa pública, no sentido de concessão a entes privados da execução de ações públicas (modelo este que surge com capitanias hereditárias e se atualiza recentemente com a apologia acrítica às Parceiras Público-Privadas e Organizações Sociais).

Dessa forma, o desenvolvimento brasileiro não é criticado propriamente por seu caráter conservador, mas pelo desmerecimento de sua própria modernização a partir de uma estratégia de industrialização. Dito em outras palavras, é como se essa modernização não tivesse um saldo positivo por não ter superado traços de atraso socioeconômico. Essa visão se soma visão depreciativa de cunho liberal que resume o sentido da formação a uma estrutura econômica desajustada e sem bons fundamentos de competividade. E mais, sendo essa modernização obra de um projeto nacional liderado pelo Estado, as razões de seu suposto insucesso estariam nos obstáculos que este Estado colocou à institucionalização da esfera econômica eficiente e empreendedoramente virtuosa.

Reflexos disso ganham evidência no "Plano Diretor da Reforma do Aparelho de Estado" elaborado no primeiro governo de Fernando Henrique Cardoso (FHC), tendo Bresser Pereira (2001) como figura proeminente que acusou os dispositivos sobre administração pública na Constituição de 1988 de retrocesso burocrático. A proposta era recriar o Estado e torná-lo de perfil gerencial. Segundo esse último autor, mesmo reconhecendo imprecisão conceitual, defendeu a necessidade histórica de tornar a administração pública compatível com a emergência de uma forte "sociedade civil" (ou seja, supostamente a organização social relevante deixaria de ser composta de classes) e uma economia também supostamente pós-industrial. Portanto, o pressupostos do projeto é adotar uma periodização que estipula uma "nova era" iniciada nas décadas finais de século XX, marcada pela 
globalização dos mercados, cuja relação entre Estado e sociedade tornaria possível negar a continuidade da representação de classe e rejeitar o papel da industrialização nos moldes nacionais-desenvolvimentistas.

Antes do golpe, após as grandes manifestações de 2013, Michel Temer já invocava a necessidade de retomada dessa agenda. Mais uma vez, utilizou-se uma periodização que destacava a importância de tornar a administração pública compatível com uma agenda dos "novos tempos". Dessa forma, ungido por um iluminismo pós-moderno, traduziu-se a busca por mais direitos em "dar espaço" para a iniciativa privada e o Estado se tornar tão eficiente quanto uma empresa privada, e isso será visto como "eficiência democrática". Em suas palavras:

Estamos vivendo uma terceira fase da democracia no Brasil desde que foi promulgada a Constituição de 1988. Depois de uma democracia liberal, de uma democracia social — que tirou mais de 36 milhões da linha da extrema pobreza —, o país está vivendo agora a democracia da eficiência, na qual é exigida eficiência do poder público e dos serviços privados, além de ética na política. (TEMER, 2013, p.3)

É importante ressaltar que Temer não se intitularia um liberal apaixonado, mas aceita um namoro envergonhado, ainda mais quando se inverte a correlação de forças e é preciso se garantir a própria sobrevivência política. Além disso, essa visão encontra respaldo no poder judiciário, evidenciando o quanto essa onda de doutrinação conservadora é ampla, considerando a democracia como a estabilidade de crenças e valores sobre parâmetros de racionalidade e moralidade de forma independente e, em certa forma, ocultando a representação dos interesses de classe. Nesse sentido, destaca-se a interpretação de Luiz Roberto Barroso (2016, p.1), ministro do STF, que sintetiza os fundamentos economicistas e sociológicos do "espantalho" a ser combatido:

Tudo depende do Estado, das suas bênçãos, do seu apoio e financiamento. Todos os subprodutos negativos advêm como burocracia, troca de favores e corrupção pura e simples. Vivemos um modelo de capitalismo que não gosta nem de risco nem de competição. Isso não é capitalismo, isso é socialismo para os ricos.

Na década de 1990, em pleno apogeu do neoliberalismo no Brasil, um dos bastiões de resistência foi o poder judiciário com uma série de ações tentando impedir a utopia dominante estruturada no poder executivo de então. Hoje, a utopia dominante não se estrutura no poder executivo, e sim no próprio poder judiciário que assume posições políticas claras. Apoiado por um poder legislativo acuado sobre a hegemonia da pequena política, o poder executivo só instrumentaliza e executa um ciclo de "reformas" que é respaldado e, em particular, não encontra mais na judicialização mecanismos de proteção social e da soberania nacional. 
Quando a Razão de Estado está no poder judiciário, a única saída é resgatar a grande política com todo o risco de serem criminalizados os movimentos de resistência pelo mesmo poder judiciário que conduz o atual projeto político federal e confere legalidade. Afinal, ele mesmo que encoraja a onda de doutrinação conservadora ao flexibilizar a interpretação sobre anteriores inconstitucionalidades que passam a ser autorizadas desde que efetivadas por deliberação política no sentido desejado. Como pontuou Souza (2015), trata-se de uma ideologia anti-estado que advoga um patrimonialismo, que aparece como apenas estatal, e se soma a uma ideologia antipopular que critica como populismo a proteção às classes dominadas. Completa-se também uma ideologia anti-nacional que nega o papel do nacionalismo econômico.

Partindo do princípio que a sociedade é composta de indivíduos e não de classes, oculta-se a base histórica da exploração e do conflito social, bem como da situação de economia periférica do país2. Por outro lado, volta-se contra o funcionalismo público assumido como "donos antes de sinecuras do que de funções" (BRESSER PEREIRA, 2001, p.228) e suposto elo fundamental para a perpetuação da indistinção entre os domínios do privado e do público. Nesse ponto, qualquer resistência à recriação do Estado é vista como um ato de uma aliança de burocratas e empresários para perpetuar a captura do Estado e estabelecer para si privilégios. Contudo, Souza (2015, p. 244-247) deixa claro o que de fato está em disputa:

Temos um capitalismo selvagem e concentrador, um debate público superficial e pobre como as histórias infantis, uma das sociedades mais desiguais e perversas do planeta, e a raiz dos problemas brasileiros é vista em um espantalho: o Estado, pois supostamente só ele é corrupto e ineficiente. (...). Na verdade, trata-se da luta entre dois projetos históricos para o Brasil, oportunidade esta que se abriu com a industrialização brasileira comanda por Getúlio Vargas a partir de 1930. (...) É esse embate entre um projeto de apartheid excludente e outro mais inclusivo que reflete a história do Brasil moderno. (...) A fragilidade das conquistas realizadas pelo segundo modelo é explicada pela manutenção da força social e econômica do modelo anterior, as quais se mantiveram intocadas mesmo depois da eventual perda de poder político.

Nesses termos, deve-se superar a falsa oposição entre Estado e Mercado. O Estado tem um papel fundamental para a ordem mundial capitalista, de tal modo que seria um equívoco considerar esta última apenas como um sistema de mercado no qual ocorrem “intervenções" - periódicas ou ocasionais - de um setor público segundo algum critério

\footnotetext{
Segundo Bresser Pereira (2001, p.224): "a progressiva substituição das classes por camadas ou estratos sociais cujo poder e renda derivam do controle do conhecimento técnico e organizacional”. Nessa visão, nível educacional e qualificação contariam mais para definir a hierarquia social do que a estrutura de propriedade e as relações de produção. Por esse viés ideológico, absolutiza-se o capitalismo como regime social ao mesmo tempo que se oculta seu caráter de dominação dado que tudo passa a depender da competitividade. É digna de nota a confissão de Bresser Pereira (2001, p.244) de que a reforma administrativa, "embora influenciada por ideias neoliberais, de fato não podia ser confundida com as ideias de direita". Aliás, o mesmo registrou que, logo que assumiu o Ministério da Administração Federal e Reforma do Estado viajou a Inglaterra para aprofundamento técnico e a experiência desse país se tornou seu principal modelo.
} 
de eficiência alocativa. É preciso assumir uma economia política do Estado sob o prisma de uma dialética entre as lógicas de poder territorial e de valorização mercantil que se entrelaçam ao longo da história, retroalimentando-se. Contudo, pondera-se que essas duas lógicas possuem conteúdos próprios que impedem uma de ser redutível à outra. De fato, elas são marcadas pela unidade e pela contradição, desenvolvendo-se de forma complementar e interdependente, mas também de forma antagônica e conflitante.

Por essa razão, é fundamental a análise da especificidade histórica para avaliar como a luta política das economias nacionais rivais pela apropriação da riqueza mundial se articula com a luta das sociedades pela proteção social diante dos efeitos disruptivos da expansão capitalista marcada por processos cumulativos de centralização do poder e do capital. Requião (2015, p.1) expôs o cerne da questão:

O controle democrático do povo, incluindo os mais humildes, sobre os destinos de seu Estado Nacional Soberano através de lideranças legítimas e comprometidas com esse povo é o que mais incomoda o grande capital internacional, as potências imperialistas, seus capatazes e as pessoas fanatizadas pelo seu discurso de ódio ao Estado Soberano e Democrático por meio da ideologia neoliberal ou da ideologia fascista. Especialmente se for um povo moreno, mestiço e herdeiro de uma grande riqueza, como o povo brasileiro. Novo fundo, a supremacia racial, ética ou classista ainda permeia as motivações daqueles que desejam subjugar povos ou classes consideradas inferiores. (...) Historicamente, quando se deseja submeter um povo a um regime colonialista sem fazer guerra, busca-se convencer o povo ou sua elite de que é bom para ele limitar a ação do seu Estado através limitações legislativas arbitrárias sobre os gastos públicos, endividamento público ou emissão de moeda.

No caso brasileiro, o golpe de 2016 significa um ponto de inflexão para o aprofundamento de uma "servidão financeira" que tende a enfraquecer sensivelmente a capacidade de ação coletiva do povo através de limites fixos e arbitrários sobre a dívida/emissão de moeda e o gasto governamental. Portanto, não é exagero afirmar que se trata de um projeto de perda de independência econômica que busca a qualquer custo negar a política para evitar a politização da sociedade sobre suas intenções reais. Assim, operações midiáticas deslocam o debate público para uma agenda vaga de combate aos vieses patrimonialistas e populistas do Estado, reacendendo o complexo de inferioridade e todos os preconceitos que desqualificam as massas populares que deixam de ser motivo de orgulho e passam a ser novamente motivo de vergonha, em particular, por suas escolhas políticas.

Rompe-se a solidariedade nacional e polarizam-se profundamente divisões e cizânias no pacto social a ponto de impor uma interpretação do Lulismo como um elemento danoso de degradação moral e incompetência na gestão pública Assim, desconsideram-se os avanços e retrocesso no seio de uma frente popular e nacionalista. Por essa razão, na próxima seção, será reavaliado o Lulismo nessa perspectiva maior. 


\section{LULISMO: OS LIMITES DE UMA MAIORIA POLÍTICA HETEROGÊNEA E SUA FRAGILIDADE COMO UMA RUPTURA EM MEIO À CONTINUIDADE}

O amplo leque de alianças que levou Lula ao governo em 20023, aliado às recorrentes crises externas que atingiram o país na segunda metade da década de 19904, transformaram a legitimidade eleitoral em grande legitimidade política o que, de maneira contraditória, não assegurou de imediato maioria congressual necessária ao governo recém-eleito5. Outro complicador estava assentado no ambiente macroeconômico. O "efeito-Lula" somado à grande vulnerabilidade externa brasileira levou a taxa de inflação, em 2002, ao patamar de 12,5\% acompanhada de grande desvalorização cambial.

Em grande medida, a "Carta ao Povo Brasileiro" antecipa uma adversa correlação de forças, induzindo o novo governo a compromissos que irão marcar - de forma profunda - a trajetória política e econômica recente, incluindo a presente crise. A aplicação imediata de uma política econômica ortodoxa foi a "moeda de troca", o que não negava per si a possibilidade de transição a um novo regime interno de acumulação, como a aplicação das políticas sociais e investimentos públicos (ou com financiamento público, via BNDES). Acrescente-se a isso o maior protagonismo do investimento estatal, notadamente da Petrobrás e o lançamento de rudimentos de planificação do comércio externo (relações Sul-Sul) aproximando o país de grandes mercados externos, notadamente a China e a Índia6 e as novas instituições financeiras/monetárias dos BRICS (como o Novo Banco de Desenvolvimento).

No âmbito interno, pari passu com tais movimentos de governo, o reordenamento da oposição ganha força com as primeiras denúncias de compra de votos (mensalão) e primeiras denúncias de corrupção que, num primeiro momento, mostraram-se capazes de derrubar um a um os principais membros do núcleo duro do governo, notadamente o então Ministro Chefe da Casa Civil (José Dirceu) e o Ministro da Fazenda (Antonio Paloc-

\footnotetext{
Um ensaio de aliança com o setor produtivo nacional estava contida na própria chapa majoritária vencedora nas eleições de 2002. O vice-presidente eleito, José Alencar Gomes da Silva (1931-1911) era um empresário bem-sucedido do ramo de têxteis, presidente da Companhia de Tecidos do Norte de Minas (COTEMINAS).

4 Refere-se às crises resultantes da contenção de liquidez internacional a partir de 1997.

5 Importante notar que nas eleições de 2002, o Partido dos Trabalhadores (PT) elegeu 91 deputados federais e apenas três governadores (Acre, Mato Grosso do Sul e Piauí). Agregando o Partido Democrático Trabalhista (PDT) e o Partido Popular Socialista (PPS - que saiu do governo em meio às denúncias do "mensalão"), apoiadores em primeira hora no segundo turno das eleições, a base expandida do governo não chegava a 200 deputados num total de 513. No Senado Federal formado por 81 senadores, esta composição (base governista expandida) continha apenas 19 senadores, sendo dez do PT.

6 Todo esse processo não deve se restringir a uma visão estática de um crescimento pautado pelo aumento dos salários e consumo $\mathrm{x}$ crescimento puxado pelo investimento. O desenvolvimento econômico é um processo cíclico que comporta momentos de maior protagonismo do consumo com outros, onde o investimento ganha força. No caso brasileiro, restringir o debate a esta falsa dicotomia pode deslocar o que há de essencial no processo. O Brasil, por exemplo, fez escolhas estratégicas em matéria de política internacional que foram essenciais ao sucesso da dinâmica inaugurada em 2003. Por exemplo, as relações Brasil-China não se restringem a uma troca desigual entre países. Afora o caráter estratégico desta relação, deve se notar os crescentes investimentos chineses no país desde então; além das possibilidades abertas de financiamento pelo recém-formado Novo Banco de Desenvolvimento (comumente chamado de Banco do BRICS).
} 
ci). Estava forjado, neste processo, o atual e poderoso condomínio oposicionista formado sobretudo pelos três principais partidos de oposição (PSDB-DEM-PPS) e o grande conglomerado midiático. Porém, o início da recuperação econômica garantiu, com folga, um segundo mandato ao presidente Lula.

Esse segundo mandato desenvolveu-se na esteira dos mais importante ciclo de crescimento das últimas décadas, levando a consolidação do mercado de consumo de massas somada a um ciclo de investimentos induzidos. Coroou-se o duplo processo relacionado entre a plena composição da base do governo, já com a importante presença do PM$\mathrm{DB}$, com o de isolamento da oposição, apesar da persistente força de seu braço midiático reproduzindo-se suas críticas a um suposto viés estatizante permissivo a crescentes doses de patrimonialismo e populismo.

Para se compreender esse processo para além do aparente, é preciso ter claro as articulações políticas que levaram aos êxitos verificados, logo, não sendo explicados somente pelo efeito demanda provocado pela China acrescido por notáveis programas sociais. Nesse sentido, os dois mandatos de Lula devem ser inseridos num contexto de transição do neoliberalismo a um Novo Projeto Nacional Brasileiro. Transição neste sentido deve ser compreendida como um processo de unidade de contrários entre um velho que persiste e novos elementos capazes de projetar um salto. Se no velho estão contidas as institucionalidades consagradas na década de 1990 (por exemplo, a política de metas de inflação e o "tripé macroeconômico"), a desindustrialização e a "Carta ao Povo Brasileiro", o novo ganha com o fortalecimento de políticas setoriais (não apenas BNDES e Petrobrás, mas também, por exemplo, complexos da saúde e militar), apoio a formalização dos negócios e a reestruturação do mercado de trabalho formal, bem como o avanço de relações mais diversificadas com o resto do mundo, incluindo amplo protagonismo brasileiro em todos os fóruns internacionais7.

Os dois governos Lula marcaram uma ruptura em meio à continuidade. Reprisaram transições anteriores, notadamente as relacionadas aos processos de Independência (1822), Abolição/República (1888-89) e a Revolução de 1930. Todas caracterizadas por

\footnotetext{
Se relacionarmos o grau de independência nacional de um país com sua capacidade interna de financiamento da produção é notável o fato de a Petrobrás ter realizado a maior operação de captação do mundo no mercado de capitais nacional. No final de setembro de 2010 esta mesma empresa captou cerca de US\$ 70 bilhões na BOVESPA. Tratou-se da "maior operação de captação do mundo" até então. O fato é uma alvissara diante de determinados fatos e processos históricos. Por exemplo, entre 1998 e 2002, o Brasil recorreu três vezes ao Fundo Monetário Internacional. Por outro lado, em 2009 o Brasil passou a ser credor desta instituição. Algo inimaginável, diga-se de passagem. Expressão de um ensaio de transição.
} 
“meias rupturas"8 levadas adiante por amplas maiorias políticas heterogêneas9. Diante de uma correlação de forças adversa Lula demonstrou capacidade política de ampliação com a formação de um governo heterogêneo unindo desde forças claramente ortodoxas (Banco Central) até desenvolvimentistas convictos (José de Alencar), porém com um núcleo programático muito claro que envolveu desde políticas sociais incisivas, políticas de conteúdo local e a uma política internacional mais autônoma.

Mas o ponto forte de um governo - claramente de coalizão - carrega dentro de si sua própria fragilidade, muitas vezes residente não somente na esteira das forças políticas em movimento. Vale destacar ao menos três pontos de fragilidade. O primeiro deles é a própria fluidez das forças políticas arregimentadas em torno do presidente Lula, notadamente o PMDB. Se por um lado, com o apoio desta força tornou-se possível colocar em execução programas sociais com alto grau de profundidade, inclusive política10, por outro lado, a própria complexidade desta força foi ficando evidente na mesma proporção em que a economia passou a emitir sinais de reversão cíclica, sobretudo no interregno entre os anos de 2012 até o presente momento 11.

O segundo ponto de fragilidade está em o governo ter subestimado a capacidade da oposição se reagrupar e o papel conferido à grande mídia neste processo. É notória a percepção para quem a mídia tornou-se, desde 2005, grande elemento de desestabilização e que claramente substituiu os apequenados partidos de oposição na condução - e tentativa - de desconstrução dos feitos dos governos liderados por Lula. Sua força impediu, inclusive, a regulamentação de artigos da constituição sobre o setor de comunicações, tratando o assunto sempre como um atentado a "liberdade de expressão". Da mesma, destaca-se o seu embate com as mídias alternativas, contraditoriamente, obstruindo o processo de concorrência e, em particular, buscando garantir para os grandes veículos as principais verbas de publicidade pública.

Por fim, o terceiro ponto, a rigidez dos compromissos resumidos na "Carta ao Povo Brasileiro" e as contradições - cada vez mais latentes - entre os estertores da transição de uma dinâmica de formação prévia de poupança, logo proibitiva ao investimento, à outra,

8 Sobre essa dinâmica histórica/política brasileira de "meias rupturas", ler: RANGEL, I.: A história da dualidade brasileira. In: RANGEL, I.: Obras Reunidas. v. 2. Rio de Janeiro: Contraponto, 2005.

9 Sobre as transições brasileiras capitaneadas por maiorias heterogêneas, ler: REBELO, A.: A chave das maiorias heterogêneas. Princípios. Ed. 68. Fev/Mar, 2003. pp. 20-21.

10 É irresistível perceber a queda da influência do antigo PFL, hoje Democratas, em sólidos redutos eleitorais - notadamente na Região Nordeste. Causa e consequência dos programas de transferência de renda e maciços programas de investimento na citada região. A região Nordeste foi a que mais cresceu no país entre 2003 e maio de 2014 a região aumentou seu PIB em 58\% frente a média nacional de 48\%. Em 2012, sua participação no PIB nacional chegou ao seu maior índice histórico, 13,5\%.

${ }_{11}$ A nosso ver, sobre o PMDB, não guarda serventia caracterizá-lo como uma força de caráter puramente fisiológica ou coisas do tipo. A compreensão da dinâmica política do PMDB guarda mais profundidade ao analisar sua história, composição e prática em correspondência com o caráter complexo do Brasil e as diferentes dinâmicas de classes sociais percebidas, regionalmente. 
mais centrada no consumo e no investimento. Uma nova ordem institucional surgia em plena contradição com outra, pretérita12. A combinação entre um programa de governo voltado à geração de empregos, valorização do mercado interno e internacionalização das empresas brasileiras com a necessidade de cumprimento de uma política macroeconômica, em grande medida, avessa a aceleração do crescimento gerou deformações que somente a superação da institucionalidade pretérita seria capaz de enfrentar. Os números são sugestivos: a relação investimentos versus PIB, e seus respectivos picos nos terceiros trimestres de cada ano, desde 2002, nunca foi maior do que $20 \%$. Sendo a maior média anual do período registrada em 2010 (19,46\%).

Além disso, a lógica desta institucionalidade permite, no máximo, contrapartida em um dos dois preços básicos. Redução da taxa de juros reclama valorização cambial. Desvalorização cambial deve ser precedida por altas taxas de juros, como temos nos anos mais recentes. A utilização da taxa de câmbio, como forma de compensar (para fins de combate à inflação) a queda da taxa de juros a partir de 2006, levou a balança comercial da indústria de transformação de superávit da ordem de US\$24,06 bilhões em 2004, para deficitária em US\$ 63,5 bilhões em 201413. Ademais, ainda que tenhamos reduzido substancialmente a taxa de juros desde 2006, a mesma ainda era demasiadamente alta em comparação aos padrões internacionais.Assim, a taxa SELIC ajustada não somente à precificação da moeda, mas também como referência geral de preços torna-se o principal elemento de inércia da economia.

Mudanças de dinâmica de acumulação devem ser precedidas por alterações profundas de ordem política/institucional. Deve-se questionar o aproveitamento insatisfatório da oportunidade aberta pela crise financeira internacional, e a consequente defensiva neoliberal, para a superação dos marcos fundamentais do Tripé Macroeconômico.

Importante fazermos menção a alguns fatos e uma conjuntura. A primeira medida do governo, em outubro de 2008, foi anunciar uma saída pelo campo fiscal com a redução do superávit primário. Por outro lado, a demora na queda da taxa de juros fora compensada com uma queda em cinco pontos percentuais durante todo o ano de 2009. Uma grande, e acertada, aposta fora anunciada em março de 2009 com o lançamento de um imenso programa habitacional, o "Minha Casa, Minha Vida". Tais movimentos indicavam o fortale-

${ }_{12}$ Um quadro contendo os componentes institucionais da dinâmica de acumulação implementado na década de 1990 pode ser encontrado em: BRUNO, M. Ortodoxia e Pseudodesenvolvimentismo: nunca dantes uma receita foi tão infeliz. Insight Inteligência. Abril, Maio, Junho/2015. p. 94-105. Este "choque de institucionalidades" foi tratado em: JABBOUR, E.; DANTAS, A. : O presente e o futuro do capitalismo brasileiro em Ignacio Rangel. Artigo no prelo em homenagem à Ignacio Rangel à publicação editada pelo BNDES/ABDE em alusão ao centenário de Ignacio Rangel e Rômulo Almeida.

13 "Déficit na indústria atinge US\$ 63,5 bilhões em 2014" - Valor Econômico. 24 de fevereiro de 2015. É evidente que a superação desta ordem punitiva à indústria e ao investimento demanda a combinação entre baixas taxas de juros e câmbio desvalorizado, algo complicado diante de uma institucionalidade que coloca o combate à inflação via compressão da demanda à frente. 
cimento do campo desenvolvimentista dentro do governo numa clara mudança em relação a um início de primeiro mandato marcado por forte aperto contracionista nos âmbitos fiscal e monetário. Logo, a questão não é somente de velocidade da transição, mas principalmente - de profundidade.

Qual o ambiente interno a uma mudança desta magnitude quando o crescimento do PIB atingiu - em pleno ano eleitoral - a casa dos 7,5\%; a taxa de desemprego, 6,7\% e a inflação, 5,9\% - portanto dentro da meta "cheia" - e com a popularidade do presidente alcançando o pico de $87 \%$ ? A necessária visão de estadista, daquele capaz de enfrentar contradições políticas e estratégicas de fundo, indicando rumos, pode ter sido nublada pela suposta euforia com a capacidade de rápida recuperação. Certamente, a visão estratégica foi prejudicada a respeito da urgência em superar as amarras das institucionalidades consagradas na década de 1990.

A substituição de Lula por Dilma ensejou um reagrupamento da oposição14. Afinal, Dilma não carregava em si o carisma e o símbolo encerrados em Lula. Ao contrário, a postura de "gerente" atribuída a ela pelo ex-presidente também refletiu um problema que se confirmou: a pouca afeição à articulação política da sucessora, exatamente o principal trunfo de Lula. Esta possibilidade refletida na personalidade difícil da presidente Dilma foi amplamente explorada. Isso provaria ser fatal num país cuja história atesta a necessidade de amplitude e necessidade de grandes arranjos políticos para a sustentação de determinados pactos políticos.

A atual crise política guarda raízes no esfacelamento da frente ampla que sustentou politicamente o projeto vitorioso nas eleições de 2002. Ao lado disso, a oposição, num processo contínuo e calculado de acúmulo de forças ancorado na grande mídia, conseguiu angariar a simpatia de uma classe média sensível a temas de cunho moral, sendo a principal deles a questão da corrupção, a ponto de, somente no primeiro ano de governo, seis ministros de Dilma serem demitidos após denúncias. Ainda assim, sua popularidade alcançou 64\% de aprovação (ótimo ou bom) em abril de 2012. Nesse sentido, a exploração da temática da corrupção não foi o estopim do processo (algo, recolocado incessantemente, peno menos, desde o caso do "mensalão" sem abalar a execução programática), e sim os velhos garrotes sobre a macroeconomia que não restringiram a capacidade de lidar com um cenário mais profundo de instabilidades desde o final de 2010. Antes disso, o movimento da taxa SELIC voltou à ascendente no mês de fevereiro de 2010 quando saiu de $8,5 \%$ para 12,5\% em agosto de 2011 segundo Banco Central do Brasil, num movimen-

${ }^{14}$ José Serra (PSDB), o candidato derrotado no segundo turno das eleições de 2010, obteve 43,95\% dos votos válidos, enquanto Geraldo Alckmin, suplantado por Lula no segundo turno em 2006, contou com 39,17\% dos votos. Esse processo de "acúmulo de forças" é consagrado nas eleições de 2014 quando Aécio Neves obtém 48,3\% dos votos válidos. 
to de contração do crédito auxiliado (desde 2011) por medidas macroprudenciais. No final deste mesmo ano o governo decidiu elevar fortemente a meta de superávit primário para $3,1 \%$ do PIB em 2011.

Segundo Serrano e Suma (2015, p. 1)15:

This rapid increase in the primary surplus was only possible thanks to a strong reduction in the growth of public spending. In 2011, public investment, both of the central government and the state-owned companies, fell dramatically, by 17.9 percent and 7.8 percent in real terms, respectively. The government's contractionary policies led to a pronounced decline in private investment as well, so that total investment (public and private) fell sharply. After growing at an average annual rate of 8.0 percent between 2004 and 2010, peaking at 18 percent in 2010, gross fixed capital formation over 2011-2014 grew by just 1.8 percent annually.

Esta decisão - ao lado das citadas demissões - consolidaram o processo de acúmulo de forças por parte da oposição. O mais interessante: em um momento de claro desgaste das concepções neoliberais no mundo e no Brasil e após o sucesso de uma orientação interna de combinação entre aumento dos investimentos públicos e expansão do consumo. Outro aspecto é o rumo da transição indicado, sobretudo a partir do segundo mandato de Lula, e a questão da oportunidade perdida de superação da ordem institucional implantada na segunda metade da década de 1990. Neste mister, certamente o aumento da taxa de juros, o anúncio de medidas macroprudenciais e a elevação do superávit primário indicam uma chance perdida num momento de grande força e prestígio tanto de Lula quanto de Dilma. E quando, talvez, intentou-se um experimento desta magnitude, sobretudo a partir de 2012, o timing político pode ter-se esvaído.

Surpreendentemente, o final do governo Lula e o início de Dilma marcaram um rompimento de cerco ao neoliberalismo nacional, passando a ser questionado que as políticas expansionistas teriam perdido espaço de folga na estrutura fiscal e que o Brasil deveria manter o rumo estratégico indicado nos anos de 1994 e 199916. Os impressionantes acontecimentos iniciados em maio de 2013 até o resultado eleitoral de 2014 marcaram um fulminante processo de acúmulo de forças por parte da oposição, capitaneada por seu braço midiático. Segundo SINGER (2015, p. 44):

\footnotetext{
15 "O rápido crescimento do superávit primário somente foi possível graças a uma forte redução no crescimento do gasto público. Em 2011, o investimento público, tanto o proveniente do governo central quanto das empresas estatais, caiu dramaticamente em $17,9 \%$ e $7,8 \%$, respectivamente. As políticas contracionistas do governo central levaram a uma queda acentuada do investimento privado, assim como do conjunto do investimento (público e privado). Após um crescimento anual de $8 \%$ entre 2004 e 2010, com pico de 18\% em 2010, a formação bruta de capital intensivo caiu em 1,8\% ao ano entre 2011 e 2014." [tradução livre dos autores]. 16 A pressão exercida pela inflação pode ser outro elemento a ser destacado. A inflação de 2011 foi de 5,9\%, a maior desde 2006.
} 
De 2011 a 2012, em iniciativa política inesperada, os desenvolvimentistas invadiram a cidadela sagrada das decisões monetárias e avançaram aos saltos, pressionando instituições privadas para reduzirem os próprios ganhos, com o apoio das divisões pesadas dos bancos públicos e de ousada mudança nas regras da poupança. Quando a refrega parecia ganha, (...), o poderoso Banco Central (BC) voltou a elevar a taxa SELIC (abril de 2013) e, na prática, devolveu ao mercado financeiro controle sobre parte fundamental da política econômica. A decisão tornava manca a perspectiva de retomada do desenvolvimento nacional (...).

Esta passagem é suficiente ao levantamento de, ao menos, três questões. A primeira, o alcance do avanço proposto com a inauguração da "Nova Matriz Macroeconômica"17 em 2012 deveria sugerir um imenso acúmulo de forças da parte do campo político liderado pelo PT que na verdade ocorreu rapidamente após a crise financeira internacional, porém sustada desde o segundo semestre de 2010. A ousada proposta de mudança na condução econômica, neste sentido; por ser inesperada, não foi precedida por preparo político prévio, talvez por menosprezar o grau de batalha à espreita. A subestimação da capacidade de reagrupação política do campo conservador mostrou-se fatal. A derrota da curta experiência, avassaladora.

A segunda que deve se inserir na passagem que incide sobre a "devolução" - em abril de 2013 - ao mercado financeiro, pelo BC, do controle sobre "parte fundamental da política econômica”. Esta devolução de poder ao mercado financeiro é parte de um todo que envolve a própria tomada, pelos liberais, do aparelho de Estado - sobretudo após o processo de redemocratização na metade da década de 1990, a eleição de Collor e os dois mandatos de Fernando Henrique Cardoso. Não deve parecer surpresa que a oposição a políticas de cunho inclusivas e desenvolvimentistas partiriam de quadros internos ao aparelho de Estado. Em particular, o Banco Central se torna a mais clara expressão de um bunker antidesenvolvimentista pronto a articular um "dumping” sobre o Estado, a partir do próprio Estado $^{18}$.

O terceiro ponto diretamente relacionado com o comportamento dos empresários. Interessante notar que em grande medida a "Nova Matriz Macroeconômica" foi ao encontro de demandas há muito colocadas por empresários, sobretudo os ligados a Federação das Indústrias do Estado de São Paulo (FIESP). Um diálogo inédito, em 2011, entre a própria FIESP e as centrais sindicais produziu um documento pontuando as medidas necessárias

${ }_{17}$ A "Nova Matriz Macroeconômica" sugeria um maior protagonismo do Estado na condução da política econômica. Na prática redundou numa queda da taxa de juros de 12,5\% para 7,25\% entre abril de 2011 e abril de 2013, certamente pressionada pela presença dos bancos públicos no mercado de crédito. Ampla atuação do BNDES que no segundo mandato da presidente Dilma desembolsou cerca de R 400 bilhões, intervenção governamental no sistema de preços do setor elétrico, desonerações fiscais e controle sobre o fluxos de capitais e políticas de conteúdo nacional e lenta desvalorização do real frente ao dólar. O rumo desta mudança radical estava no correto diagnóstico para quem a manutenção do progresso social obtido nos anos Lula demandava crescimento econômico anual da ordem de $5 \%$.

18 Sobre este fenômeno, destaca-se trabalho anterior em: JABBOUR, E.: Plano Real (1994): o banditismo de Estado no poder. Portal Vermelho, 07/04/2014. Disponível em: http://www.vermelho.org.br/coluna.php?id_coluna_texto=5871\&id_coluna=17 
à contenção da regressão industrial verificada desde a década de 199019. Porém, o que se verifica no desenrolar do processo foi um lento, porém firme, distanciamento do empresariado em relação ao governo - a ponto de se tornar uma das bases de apoio ao impedimento da presidente Dilma.

Ademais, em 2011, ao "retirar" do sistema financeiro a prerrogativa de determinar o preço da moeda, faltou ao governo uma leitura exata da transmutação do grande empresário industrial em rentier, dada a natureza da própria dinâmica de acumulação inaugurada na década de 1990. Soma-se a isso uma firme resposta destes mesmos empresários ao processo de fortalecimento da classe trabalhadora como causa e consequência de uma situação de quase pleno emprego20

A transformação da contraofensiva conservadora de uma "guerra de posição" ao patamar de "guerra de movimento" necessitava de certo apelo capaz de mobilizar a classe média que desde as eleições de 2010 se deslocava do governo. A formação de uma sólida base social estava na ordem dos acontecimentos. A oportunidade surgira com a eclosão das manifestações de junho de 2013. O movimento inicia-se como contestação a aumentos da tarifa de ônibus, primeiramente, em São Paulo. Transbordando para pautas avessas ao Estado e, consequentemente, a política. Assim, a versão conservadora resumiu o Lulismo a um mero acordão político espúrio de aparelhamento e negociatas, parcialmente ocultado por um aproveitamento de uma bonança externa (visto basicamente como um "bilhete premiado") que, passado seus efeitos, descortinou sua incapacidade de consolidar a agenda de estabilidade e sujeito a extravagâncias heterodoxas que puseram em risco o suposto aperfeiçoamento do Estado em prol de um viés gerencial.

As manifestações de junho assentam dois movimentos que foram fundamentais ao isolamento do governo e o fim da experiência da "Nova Matriz Macroeconômica". O primeiro movimento foi o de desembarque do empresariado produtivo do governo, agora em aliança aberta com o rentismo. O segundo diretamente relacionado com a captura das manifestações pela mídia que tardou a abraçar as possibilidades abertas pelo movimento, e, ao abraçá-las, tratou de utilizá-la no sentido de pautar ao governo a necessidade de mudanças profundas na política econômica para um maior alinhamento aos compromissos anteriores. A retórica contra a política e os políticos atingiu seriamente a popularida-

19 Trata-se do texto, Brasil do diálogo, da produção e do emprego. Federação das Indústrias do Estado de São Paulo. Disponível em: http://www.fiesp.com.br/brasil-do-dialogo-pela-producao-e-emprego/

20 Amparado em estudos do professor Ruy Braga, André Singer aponta o aumento do poder de barganha da classe trabalhadora o que, per si, guarda motivo suficiente a um afastamento do capital industrial, seja do governo, seja de uma linha tênue de aliança com os trabalhadores conforme se lê (SINGER, 2015, p. 65): "O número de paralisações, que já vinha subindo desde 2008, atingiu quase 87 mil horas paradas em 2012, o maior índice desde 1997, e continuou a crescer. Segundo Braga, houve 873 greves em 2012 com um salto para mais de 2 mil em 2013". 
de da presidente. Antes das manifestações o "ótimo e bom" que era de 65\% em março de 2013 caiu para $30 \%$ no final dos protestos 21.

O cerco ao desenvolvimentismo fora consolidado. A reação do governo atesta isso, conforme Singer (2015, p. 56-57)22:

Ao reagir à onda de protestos, Dilma propôs a responsabilidade fiscal como o primeiro dos cinco pactos que deveriam reunificar a nação e, no final de julho de 2013, promoveu um corte de 10 bilhões de reais no orçamento de 2013, 'em resposta, sobretudo, ao mercado financeiro, que o acusa [ao governo] de leniência com a inflação'. No começo de 2014, o gasto público foi outra vez cortado, abandonando-se o projeto de lei que reduzia as dívidas de estados e municípios. A prefeitura estratégica comandada por Haddad viu-se estrangulada, pondo em perigo o futuro da gestão. Some-se à contenção dos gastos públicos os juros sempre em elevação, e será compreensível que o crescimento do PIB em 2014 tenha sido zero. A política monetária e fiscal contracionista, junto com a profunda desconfiança da burguesia, anulara as tentativas da nova matriz de elevar o investimento, o qual apresenta uma queda de 4,4\% em 2014. Com o declínio da atividade econômica, cai a arrecadação, deixando o Estado vulnerável às propostas de ajuste fiscal que se tornarão ubíquas.

Os passos seguintes deste processo foram marcados por uma precipitação de acontecimentos que levaram ao impeachment da presidente Dilma Roussef. Prejudicada por movimentos audaciosos do presidente da Câmara, Eduardo Cunha - que por sua vez contou com uma ampla unidade tática da oposição em torno do impeachment23, da amplificação "just in time" dos primeiros resultados da Operação Lava Jato e de um processo de transformação em movimento de massas de um movimento de características ultraconservadoras -, teve seu governo enfraquecido e em rápido processo de isolamento político e institucional24.

Um senso comum paira sobre o país quando o assunto é a crise política que culminou no impedimento da presidente Dilma Roussef. É recorrente o parti pris para quem a cri-

${ }^{21}$ Popularidade de Dilma cai 27\% após protestos. Folha de S. Paulo, 29/06/2013. Disponível em: http://www1.folha.uol.com.br/ poder/2013/06/1303541-popularidade-de-dilma-cai-27-pontos-apos-protestos.shtml

22 Uma análise análoga a de Singer, e mais recente (às vésperas da votação do impeachment na Câmara dos Deputados), foi elaborada por Perry Anderson: Crisis in Brazil. London Review of Books. V. 38, n 38. 21 April 2016.

${ }^{23}$ À análise deste processo guarda centralidade o acordo de unidade tática da oposição tendo em vista que durante boa parte da crise política uma unidade estratégica em torno da necessidade de deslocar as forças sustentadoras do projeto vencedor em 2002, 2006, 2010 e 2014 nunca fora acompanhada por uma unidade de caráter tática. Unidade esta que redundou num consenso conservador em torno da necessidade de impedimento da presidente da República.

${ }^{24}$ Existem características brasileiras no que se refere à situação de "isolamento político-institucional" da presidente da República. Na verdade, uma visão larga da referida situação deverá remeter ao papel exercido por órgãos de Estado no processo, notadamente o poder judiciário, o Ministério Público e a Polícia Federal. Órgãos estes compostos - em sua maioria - por membros advindos da pequena burguesia de grandes centros urbanos. Com forte viés moralista tiveram papel de proa ao formar uma unidade em torno das investigações da Operação Lava Jato conduzida por um juiz de primeira instância (Sérgio Moro), habitué de cursos de formação contra crimes fiscais oferecidos pelo Departamento de Estado dos EUA, influenciado pela experiência da Operação Mãos Limpas (Itália). Na ponta do processo podemos, tranquilamente, admitir que houve um golpe institucional levado a cabo por aparelhos do próprio Estado cujos processos judiciais naturalizaram práticas dignas de um verdadeiro estado policial, de exceção. 
se política é decorrência de uma crise econômica que, por sua vez, tem na crise fiscal sua face mais visível. Se existe alguma ponta de verdade nesta afirmação, ela deve ser buscada numa atitude que variou da euforia à extrema hostilidade por parte do empresariado com as induções indicadas na "Nova Matriz Macroeconômica" e as desonerações fiscais anexas a uma política de troca do investimento público pelo seu congênere privado25. Afinal, os números da economia brasileira até 2014 não servem de base a uma explicação convincente sobre as causas da crise política, como se verá na próxima seção.

\section{O ANTIMILAGRE ECONÔMICO: A NATUREZA DAS CONQUISTAS, DOS LIMITES E DAS CONTRA- DIÇÕES SOBRE A DINÂMICA DE CRESCIMENTO}

A crise cambial brasileira de janeiro de 1999 impôs a necessidade de mudanças importantes na condução da política econômica local, considerando-se a impossibilidade de continuação do modelo de âncora cambial utilizado no Plano Real de 1994, que operava como seu principal alicerce26. Com a necessária variação para um regime de câmbio flutuante, a taxa de juros passou a operar como variável básica de controle da inflação, a partir da adoção do modelo de metas de inflação. De acordo com Ferreira e Jaymer Jr. (2005, p. 2), o sistema de metas inflacionárias é

Caracterizado pelo anúncio oficial de uma meta de crescimento para algum índice de preço escolhido a priori para um determinado período [...]. Assim, tais metas coordenariam a formação de expectativas inflacionárias dos agentes e a fixação de preços e salários.

Neste contexto, a política fiscal passa a exercer um papel de variável de ajuste no modelo - como a taxa de juros impacta a dívida pública pelas despesas financeiras, seria necessária a obtenção de superávits primários no intuito de impedir uma trajetória explosiva das contas públicas.

Apesar das mudanças ocorridas, a ideia central que domina a formação da política econômica é a mesma que orienta a gestão do Plano Real, definindo a estabilidade de preços relativos como determinante crucial para a criação de um ambiente favorável ao crescimento econômico com competitividade. Nesse caso, segundo Dantas (2013, p. 67-68),

${ }^{25}$ Conforme já indicado, a troca dos investimentos públicos por políticas típicas pelo "lado da oferta" tornou-se um erro estratégico fatal.

${ }^{26}$ A âncora cambial serviria como instrumento fundamental de controle dos preços relativos, em um ambiente de liberalização comercial e financeira. De acordo com Dantas (1998), a âncora cambial contribuiu para a "elaboração de planos de estabilização do nível de preços de grande sucesso em seus objetivos iniciais. A ideia básica assumida por estes planos era garantir uma flutuação interna de preços que seguisse a trajetória internacional. Para isso era necessário que se efetuasse uma abertura comercial (e câmbio fixo, ligeiramente valorizado) de forma que, inicialmente, os tradables fossem pressionados pela concorrência internacional, comprimindo margens de lucro e estabilizando, internamente, seus preços. Em cadeia, este processo acabaria por atingir (em maior ou menor grau), o conjunto de produtos não tradables da economia permitindo a estabilização geral do nível de preços. Uma vez atingido este objetivo, mecanismos tradicionais de política monetária seriam suficientes para alongar o prazo da estabilização da moeda - com apenas um problema: a manutenção do câmbio fixo e valorizado, engessando instrumentos mais diretos de política cambial" (p. 12). 
Quanto à questão do crescimento econômico, a conjugação das metas inflacionárias com uma política fiscal austera garantiria, de acordo com o modelo adotado, a estabilidade econômica requerida, oferecendo aos agentes econômicos um cenário propício para as decisões de investir. A capacidade de elevar as taxas de crescimento resultaria, em última instância, do aumento de produtividade dos fatores de produção, desde que os mecanismos de mercado atuassem sem interferências, sobretudo no que diz respeito aos preços relativos estáveis e à conformação de um ambiente favorável ao aumento da concorrência na economia (em especial a concorrência externa).

A chegada de Lula à presidência em 2003, após uma vitória eleitoral com larga margem em 2002, não trouxe mudanças na condução da política econômica, mantendo o tripé definido após 1999 (câmbio flutuante, metas de inflação e austeridade fiscal) e as regras institucionais então vigentes, com destaque para uma atuação independente do Banco Central na condução da política monetária e a Lei de Responsabilidade Fiscal. Na verdade, o quadro já tinha sido definido desde antes da eleição de 2002. A viabilidade crescente de câmbio de poder político, com a iminente vitória de Lula, criou um cenário de incerteza $\mathrm{e}$ instabilidade, principalmente pela atuação fortemente especulativa dos agentes financeiros. Desta forma, Lula garante em carta aberta (a assim chamada "Carta ao Povo Brasileiro") a manutenção da estabilidade institucional e da política econômica.

Os gráficos 1 e 2 mostram a efetiva manutenção do compromisso assumido, incluindo o primeiro mandato presidencial de Dilma Roussef iniciado em 2010. De acordo com a Figura 1, pode-se observar que o resultado primário do setor público foi mantido em superávit ao longo de todo o período, com redução apenas nos anos em que houve redução no ritmo de crescimento da atividade econômica, como em 2009 e 2014. A Figura 2, por sua vez, assinala o comportamento estável da inflação nos mesmos anos, sempre dentro das metas de inflação definidas.

Apesar da continuidade visualizada, entretanto, uma importante ruptura passa a ocorrer, sobretudo a partir de meados do primeiro mandato de Lula com a ampliação dos programas de transferência de renda e a criação de novos mecanismos fundamentais de políticas sociais e de desenvolvimento econômico. Destacam-se aí a política de valorização real do salário mínimo e a elaboração de programas de investimento na infraestrutura e oferta crescente de crédito, principalmente via BNDES (Banco Nacional de Desenvolvimento Econômico e Social). 
Figura 1 - Resultado primário do setor público - Brasil - 2002/14

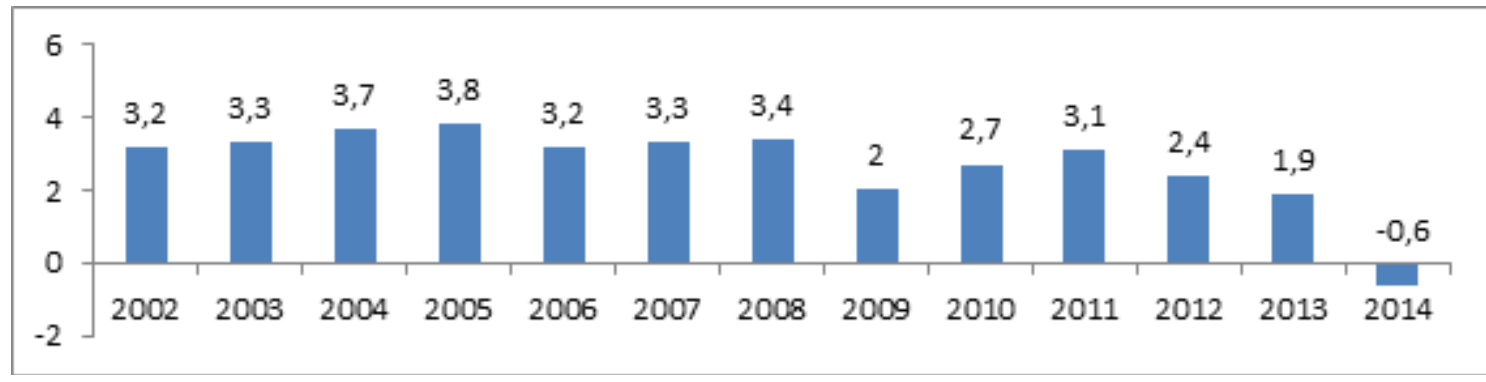

Fonte: Elaboração própria a partir de Economia Brasileira em Perspectiva - Ministério da Fazenda - 2014

Figura 2 - Inflação anual (IPCA) - Brasil - 2002/14

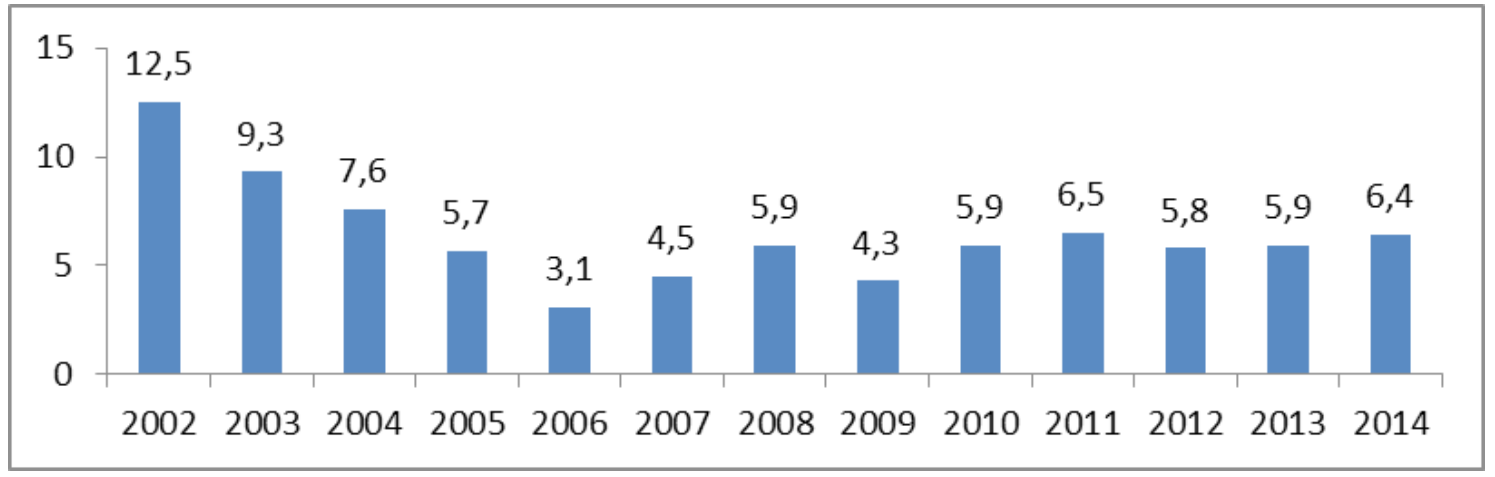

Fonte: Elaboração própria a partir de Economia Brasileira em Perspectiva - Ministério da Fazenda - 2014

Os resultados foram evidentes. Em primeiro lugar, a combinação de crescimento das despesas com transferências (com papel central para o programa Bolsa Família) e, mais importante, do expressivo aumento real do salário mínimo (e, por consequência, do salário médio real no Brasil), determinou uma redução drástica da parcela de pessoas em situação de extrema pobreza no país, além de uma melhora substancial nos índices de distribuição de renda. Além disso, registrou-se um aumento efetivo nas inversões nos setores de infraestrutura e nos créditos fornecidos pelo BNDES. Como mostram as Figuras 3 e 4, o salário mínimo real aumentou cerca de $76 \%$ entre 2002 e 2014, enquanto o rendimento médio real do trabalho elevou-se em aproximadamente 36\% (2002 a 2013). 
Figura 3 - Salário mínimo real - Brasil - 2002/14

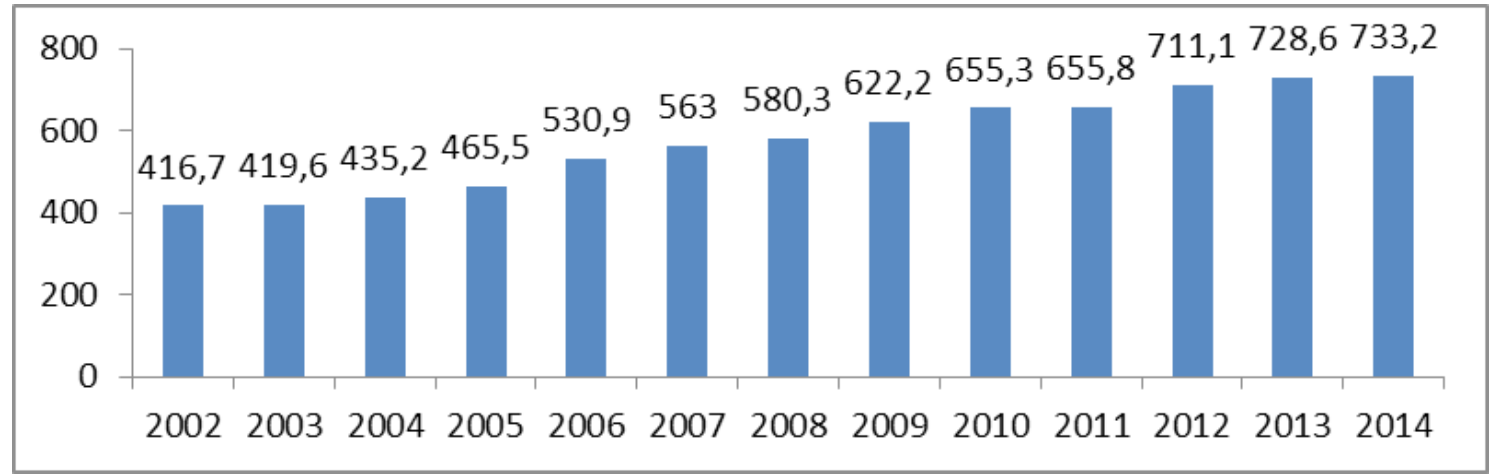

Fonte: Elaboração própria a partir de Economia Brasileira em Perspectiva - Ministério da Fazenda - 2014

Figura 4 - Rendimento médio real - Brasil - 2002/13

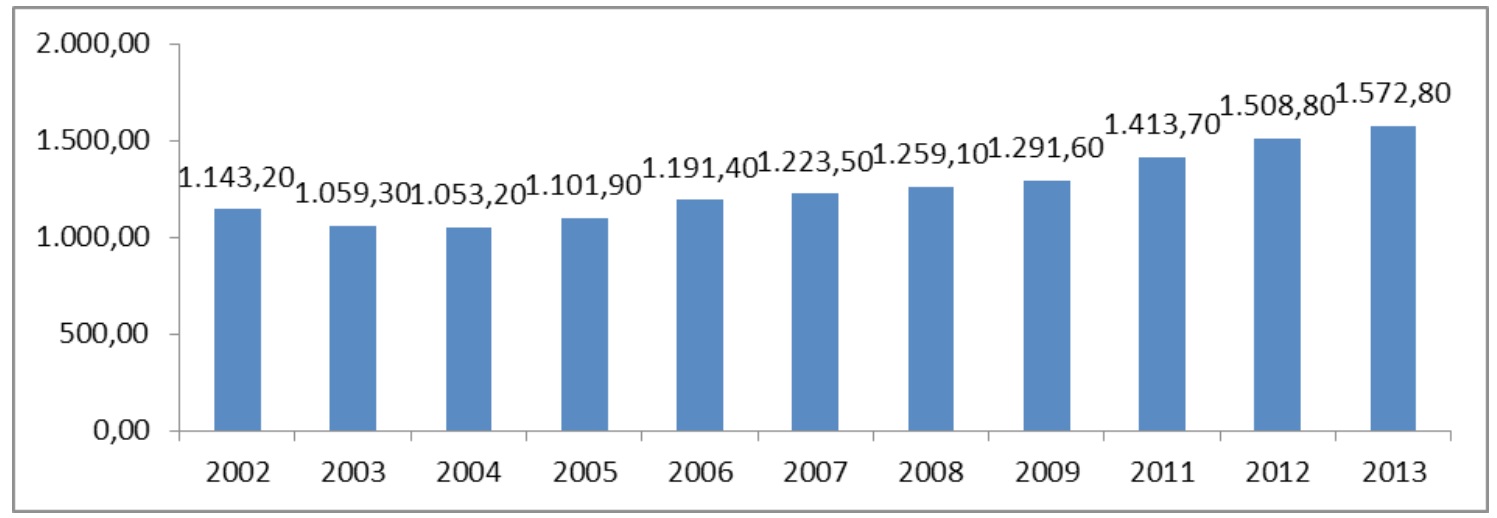

Fonte: Elaboração própria a partir de Economia Brasileira em Perspectiva - Ministério da Fazenda - 2014

Ao mesmo tempo, os dispêndios do BNDES foram 5 vezes maiores em 2014 que em 2002, com forte aceleração a partir de 2008/9. Já os investimentos em infraestrutura foram 3,2 maiores em 2013 frente a 2014 - gráficos 5 e 6.

\section{Figura 5 - Créditos do BNDES - Brasil - 2002/14}

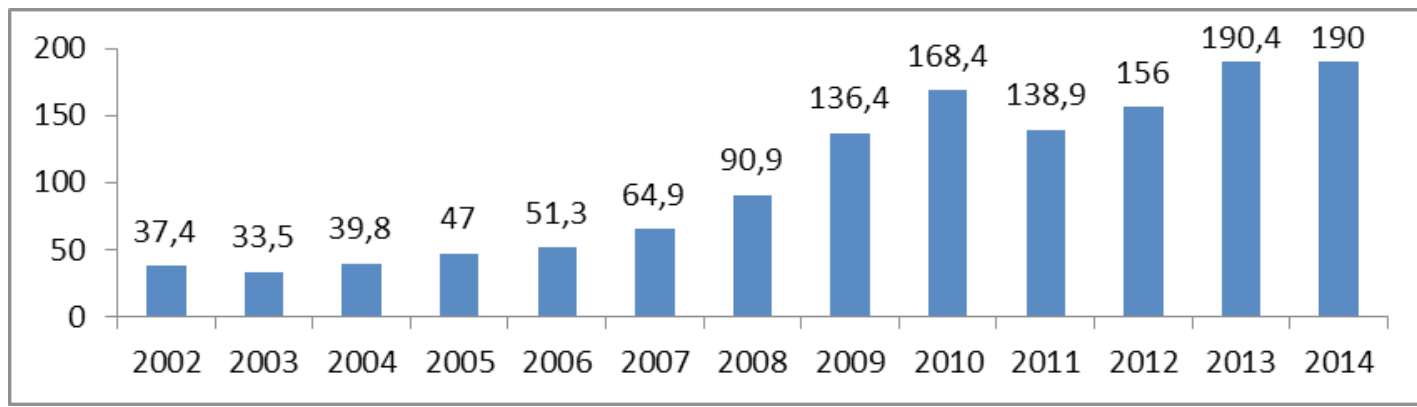

Fonte: Elaboração própria a partir de Economia Brasileira em Perspectiva - Ministério da Fazenda - 2014 
Figura 6 - Investimentos em infraestrutura - Brasil - 2002/13

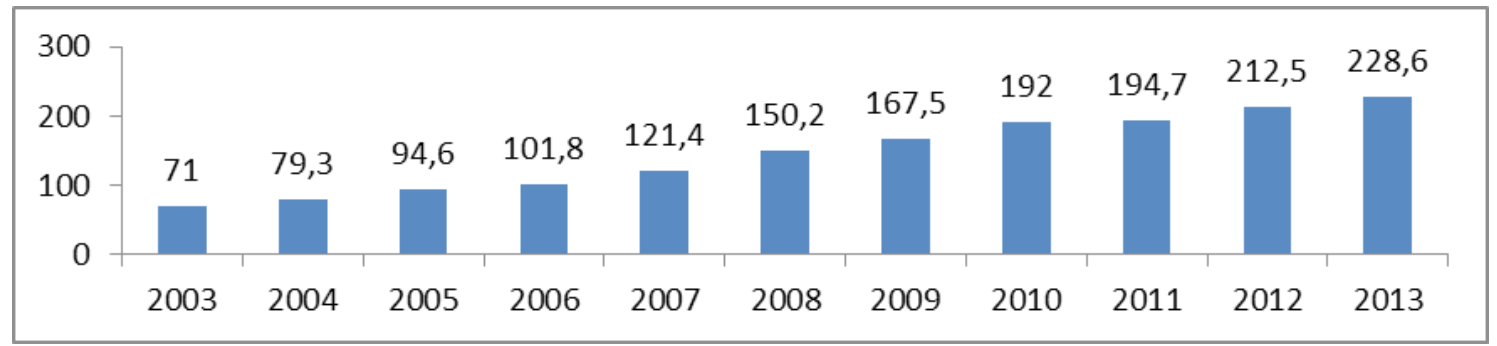

Fonte: Elaboração própria a partir de Economia Brasileira em Perspectiva - Ministério da Fazenda - 2014

Em segundo lugar, esses fatores conjugados inauguraram um novo vetor de crescimento da economia brasileira, cujo pilar fundamental passou a ser a evolução da massa salarial e seu impacto para o consumo das famílias27, mas contando também com aumento importante da taxa de investimento no Brasil28. As Figuras 7 e 8 apresentam a evolução da massa salarial e do consumo das famílias no período de análise. A massa salarial cresceu cerca de $2 / 3$ entre 2002 e 2013, enquanto o consumo das famílias registrou taxa de crescimento positiva entre 2004 e 2014, em especial até 2010 (crescimento médio de $4 \%$ ao ano entre 2006 e 2014). A partir de 2011, este modelo passa a perder força, apesar de manter taxas sempre positivas - tema que será retomado à frente.

\section{Figura 7 - Massa salarial real - Brasil - 2002/14}



Fonte: Elaboração própria a partir de Economia Brasileira em Perspectiva - Ministério da Fazenda - 2014

${ }_{27}$ Vale ressaltar ainda o papel do inconteste aumento do crédito ao consumidor e da expansão do crédito consignado no Brasil.

28 A taxa de investimento chegou, após muitos anos, perto dos 20\% do PIB (19,5\% em 2010), perdendo força a partir de então, mas ainda em níveis superiores a 2002. 
Figura 8 - Taxa de crescimento do consumo das famílias - Brasil - 2002/14



Fonte: Elaboração própria a partir de Economia Brasileira em Perspectiva - Ministério da Fazenda - 2014

Em terceiro lugar, com o maior ritmo de crescimento empreendido pela economia brasileira (particularmente entre 2004 e 2010), registrou-se uma redução significativa da taxa de desemprego, que saiu da casa dos dois dígitos que marcou o índice desde os anos 1990 para 4,8\% no final de 2014. Vale destacar ainda que a taxa de desemprego brasileira apresentou uma trajetória de queda constante desde o início do primeiro governo de Lula, com exceção apenas do ano de 2009, auge da crise financeira internacional, quando subiu 0,2\% relativamente ao ano anterior (com queda do PIB de 0,3\%) - Figuras 9 e 10.

Figura 9 - Variação anual do PIB - Brasil - 2002/14

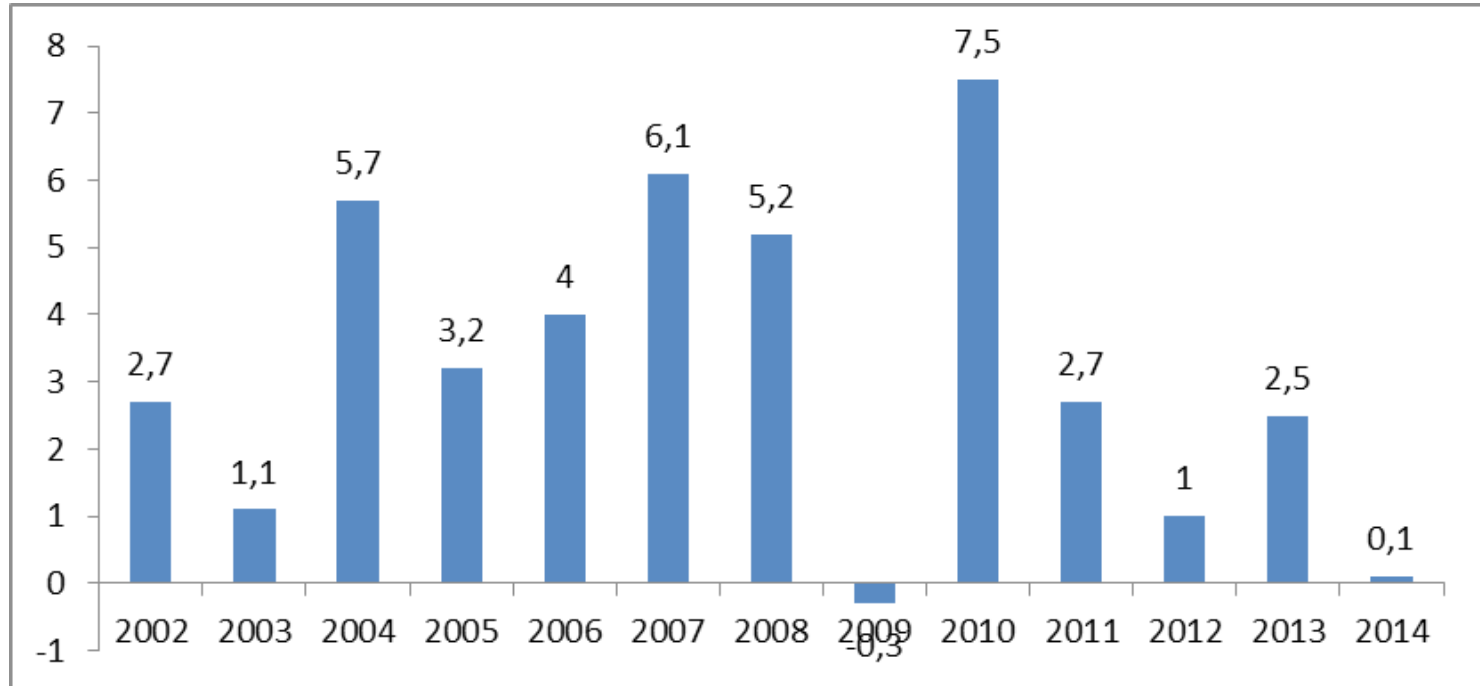

Fonte: Elaboração própria a partir de Economia Brasileira em Perspectiva - Ministério da Fazenda - 2014 
Figura 10 - Taxa de desemprego - Brasil - 2002/14

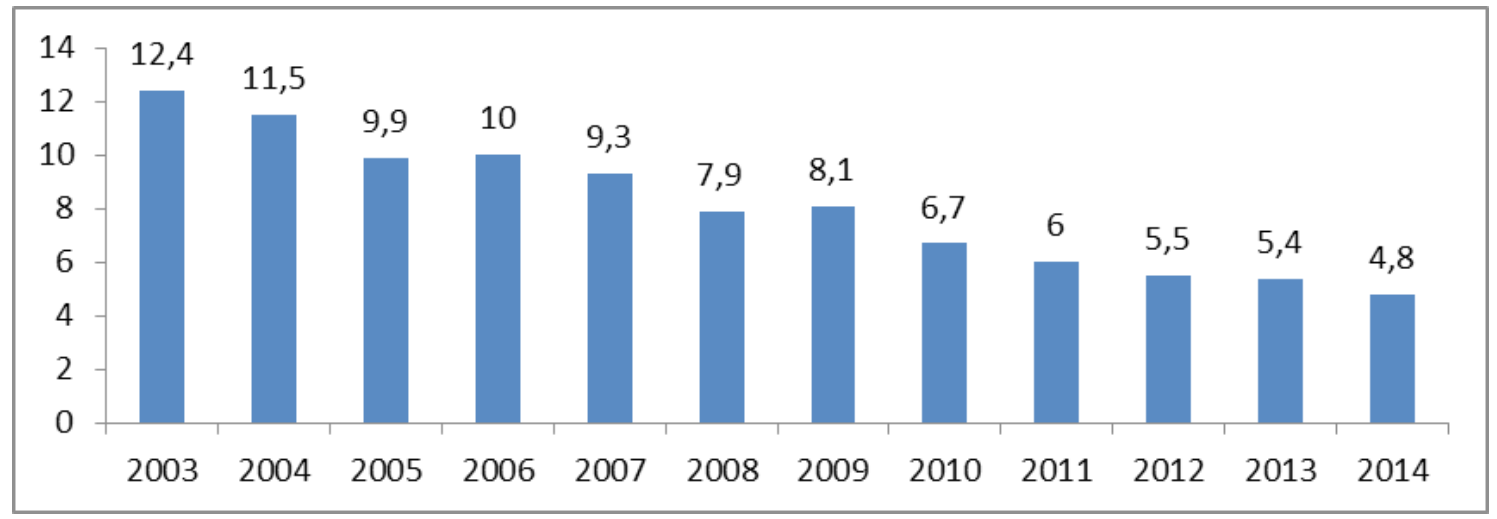

Fonte: Elaboração própria a partir de Economia Brasileira em Perspectiva - Ministério da Fazenda - 2014

Finalmente, cabe acrescentar que, mesmo considerando o aumento real do salário mínimo e do rendimento médio real abordados anteriormente, a criação de empregos formais seguiu crescendo forte ao longo do período, embora claramente venha perdendo força desde 2012 - ver Figura 11.

Figura 11 - Criação de emprego formal - Brasil - 2002/14

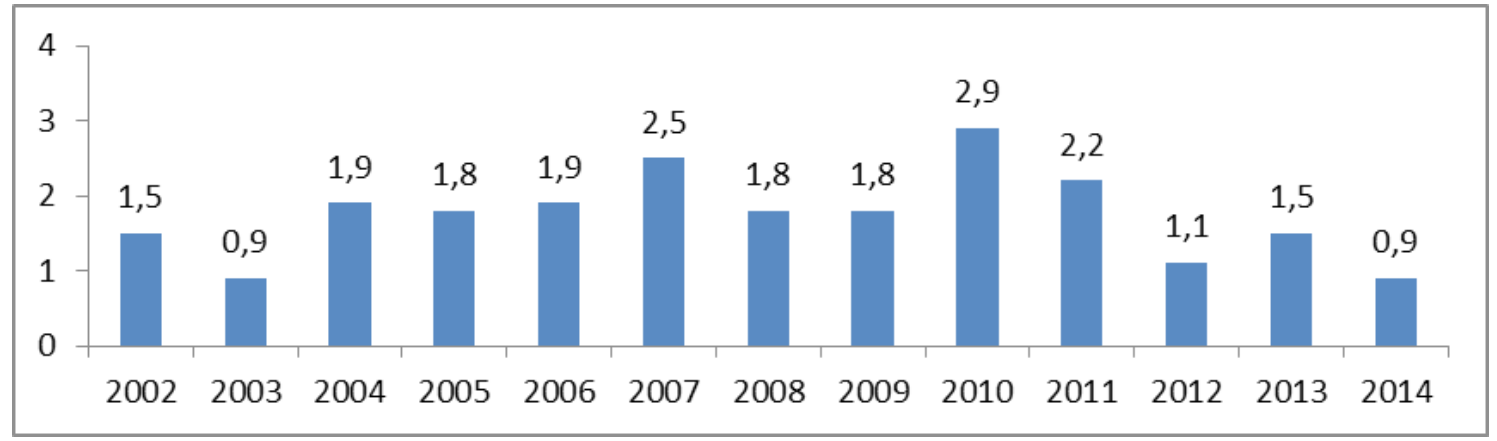

Fonte: Elaboração própria a partir de Economia Brasileira em Perspectiva - Ministério da Fazenda - 2014

Observa-se, portanto, que os números da economia brasileira não indicavam qualquer tendência a uma inflexão mais radical de desempenho, talvez introduzindo, no máximo, uma necessidade de reorientação de alguns movimentos de política econômica, sobretudo na contenção de um possível (mas ainda incerto, até 2014) descontrole inflacionário (um aumento para 6,41, já próximo ao teto, com expectativas de elevação). Isso tudo em um ambiente de retração do ritmo de crescimento a partir de 2011, principalmente. Do ponto de vista fiscal, nenhuma grande mudança até 2014, mas com uma menor capacidade de arrecadação em função do menor crescimento do PIB - quadro distante uma crise fiscal anunciada de grandes proporções, principalmente pela oposição nos debates da eleição presidencial. 
No que se refere ao quadro externo, a despeito da piora das condições das transações correntes, e a expectativa de queda continuada no preço das commodities e seus efeitos para a exportação brasileira, a situação das reservas acumuladas (Figura 12) ao longo dos anos anteriores garantia uma confortável possibilidade de gestão do balanço de pagamentos, sem qualquer prenúncio viável de crise externa (mesmo considerando a possibilidade e os pré-anúncios de perda do grau de investimento conferido ao país pelas agências internacionais de risco, cada vez mais questionadas no mundo quanto à sua credibilidade).

Figura 12 - Reservas internacionais - Brasil - 2002/14

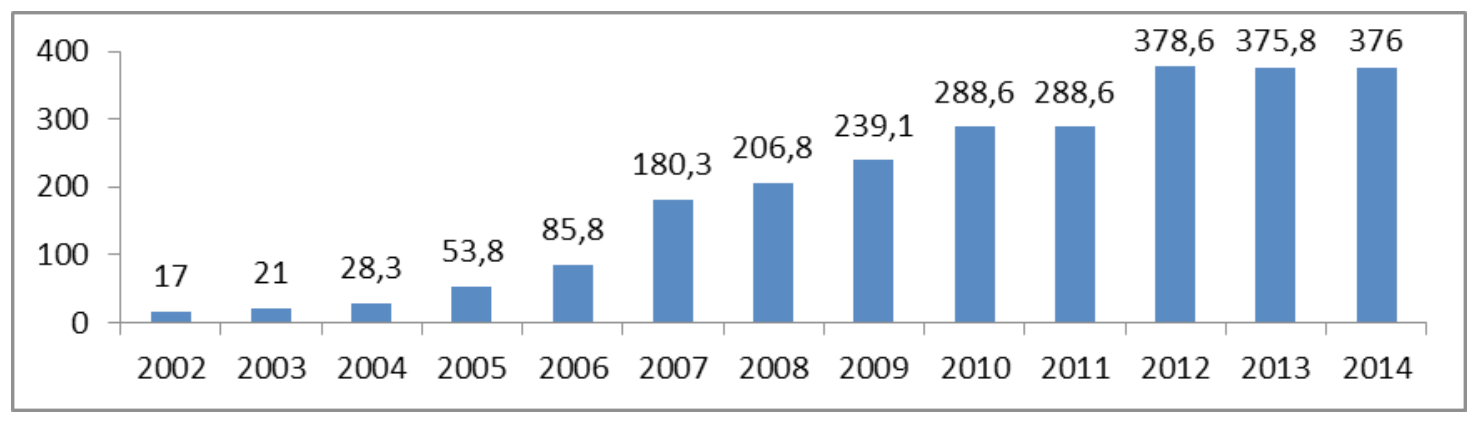

Fonte: Elaboração própria a partir de Economia Brasileira em Perspectiva - Ministério da Fazenda - 2014

Todavia, o que se verificou foi uma forte reversão no contexto econômico brasileiro, com uma recessão importante em 2015 (queda de 3,8\% do PIB), forte acirramento do processo inflacionário (o IPCA atingiu a marca de 10,7\%) e, ao mesmo tempo, uma deterioração rápida e abrangente do resultado fiscal, tanto pelo viés primário (o déficit primário subiu para 1,9:\% do PIB) como, sobretudo, do déficit nominal, obviamente alavancado pela forte alta da taxa básica de juros no país (a dívida pública saltou de 33,7\% em 2014 para $38,3 \%$ ao final de 2015). O resultado imediato foi o rápido avanço da taxa de desemprego (chegou a 6,8\% no ano) e uma crescente insatisfação popular, ainda inflada pelas denúncias de corrupção cada vez mais abrangentes.

Nesse contexto, cabe se interrogar o que explica uma crise econômica que se tornou tão profunda em pouco espaço de tempo, considerando um quadro (efetivo e potencial) absolutamente distinto até meados de 2014.A presente crise econômica deve ser vista como o produto de uma deliberada coalisão conservadora que radicaliza para travar de vez o processo de transição em marcha pelo Lulismo do neoliberalismo a um Novo Projeto Nacional Brasileiro. Primeiro, tentou-se dar um golpe interno no seio do bloco de poder, endurecendo os termos das alianças e impondo maiores concessões que significassem a traição de sua programática. Na medida que os péssimos resultados de 2015 foram criticados não por seus equívocos decisórios e sim por falta de confiança na política econômica, buscou-se as condições objetivas para deliberar um golpismo de caráter explícito. 
Cabe assinalar sua tática e sua estratégia. Do ponto de vista tático, conduz uma "ditadura da maioria" que pretende profundas mudanças na constituição federal desconsiderando as contribuições críticas advindas do debate social, comunica-se com a população apenas em busca de propaganda e consentimento alarmista ao reiterar que não haveria alternativas29. Cabe se interrogar se uma atitude acrítica é possível de ser considerada responsável. Deve-se ter o máximo de cuidado ao afirmar que democracia é o governo de uma maioria, pois se o poder estiver em suas mãos e só seguir seus desejos se trata da tirania de um grupo a qual nem se quer significa a maioria da população.

Com o golpe de 2016, o Brasil passou a ser governado por uma maioria pluripartidária sem que existe uma maioria da população identificada com a mesma, uma maioria não advinda de um consenso e sim do respaldo, explorado midiaticamente, dos próprios órgãos de controle do governo e judiciário para serem interventores da ordem constitucional. E, por essa razão, essa elite auto-designada sob a aprovação plutocrática governa sem consultar diretamente a população, sem os eleitores servirem de base ao processo de repactuação social ou a constituição não ser violada naquilo que resguardar direitos fundamentais como é essencial em qualquer democracia.

Cabe enfatizar que a vontade geral, a vontade do povo, não se confunde com os excessos de uma facção majoritária de representantes que supera qualquer limite legal para não ter barreiras formais aos seus desejos de onipotência. O fundamento básico da democracia é o esforço de libertar o povo de todas formas de servidão, inclusive, a servidão a uma facção majoritária e seus apoiadores econômicos, o que se traduz em uma "servidão financeira". Pior que a ditadura de um homem, é a ditadura da maioria, pois contra um déspota a maioria pode se insurgir contra. Na ditadura da maioria, qualquer oposição é sufocada na ausência de limites objetivos à extensão do seu poder real. Por isso, a base do constitucionalismo é dizer que a maioria não pode tudo, a maioria tem limites constitucionais. Democracia não é a onipotência da maioria eleita, mas o seu governo baseado no respeito ao Estado de direito, logo, não podendo se alterar a constituição de forma banal como apenas mais um ato de poder.

Já do ponto de vista estratégico, sua principal base está em uma "profissão de fé" a respeito da capacidade de dar credibilidade e sustentar expectativas mais favoráveis sobre a gestão pública, midiaticamente colocada como o grande mal nacional. Cabe destacar alguns aspectos que enfraquecem essa perspectiva: 1) Equivocada escalada de juros quando não há séria inflação de demanda e há economia desaquecida, o que garante alta ren-

\footnotetext{
29 Uma prova de como esse argumento é falacioso está ao não se contrapor as questões colocadas no documento: "Austeridade e Retrocesso" (2016), iniciativa do Fórum 21, Fundação Friedrich Ebert, GT de Macro da Sociedade Brasileira de Economia Política (SEP) e Plataforma Política Social.
} 
tabilidade ao sistema financeiro em detrimento do setor produtivo; 2) Política monetária descolada da política de ajuste fiscal, pois o aumento dos juros eleva a relação dívida bruta-PIB e revela descoordenação entre metas do Banco Central e da Fazenda; 3) A manutenção de elevadas reservas cambiais a um pesado custo fiscal em um momento de ajuste pelo receio de um ataque especulativo não visível a curto prazo; 4) não existem resultados significativos que indiquem coordenação sobre a desalavancagem financeira das empresas e redução do grande impulso à desindustrialização, sobretudo a partir da crise internacional de 2008, inclusive, reflexos disso levam a uma grande pressão importadora que desajusta as contas externas e aumentam o risco inflacionário

Os limites do Lulismo não foram por excesso de intervencionismo do Estado na economia nem por um exagerado estímulo anterior ao consumo das famílias. Ao contrário, os erros foram por uma política macro pró-crescimento acanhada, indireta e, inclusive, com ações em sinais trocados. Pagou-se o preço da hesitação em assumir um perfil de atuação mais ativo na condução dos investimentos públicos e de uma política anticíclica que em certo momento passou a ser articulada de forma errada. No entanto, ao invés de estar em pauta a recuperação do investimento público e os ajustes necessários na política anticíclica, houve uma inflexão para os choques recessivos de cunho liberal na expectativa de que gerariam retomada da credibilidade. Diante do insucesso, a visão dominante ainda continuará a insistir que se está pagando por uma gastança pública de governos irresponsáveis anteriores.

Em recessão, nossa pressão inflacionária não é de demanda e sim de custos produtivos. E quanto maior a recessão, mais intensa essa pressão a partir dos custos. Do ponto de vista macroeconômico, uma redução dos juros seria fundamental para enfrentar isso. Porém esse estímulo ao crescimento é impedido e os juros ficam em altos patamares para evitar uma "fuga de capitais" em um contexto de câmbio flutuante e frouxos controles internos sobre os fluxos financeiros.Isso cria impactos negativos nas contas públicas que se deterioram a medida que se precisa dobrar a aposta em manter o valor da moeda perante a elevação do "prêmio de risco" no mercado financeiro global. Isso tira autonomia da política pública que fica refém de buscar superávits fiscais para garantir minimamente uma estabilidade monetária de forma temporária. Porém, o mais grave que essa forma de buscar a estabilidade impede o governo de investir e gradativamente vai deteriorando a competitividade nacional com custos produtivos crescentes.

Em um contexto de incerteza crônica e sob essa armadilha descrita anteriormente, torna-se mais difícil o golpismo atual usar da mesma estratégia de "fuga para frente" da ditadura militar. Prática essencial em qualquer ordem autoritária, como a atual, é garan- 
tir algum crescimento econômico para apaziguar as pressões políticas e sustentar um voto de confiança no governo. Contudo, é difícil surgir um equivalente "milagre" econômico redentor para o golpismo. Existem graves restrições de longo prazo, cuja centralidade está na questão da infraestrutura como principal vetor potencial para uma aposta. Aliás, vetor já identificado desde o final do segundo governo Lula, porém, ainda não acionado significativamente até agora. Equívocos no marco regulatório e sistema de financiamento ainda não possuem soluções adequadas.

Além disso, também existem graves restrições de curto prazo. Afinal, será preciso um esforço expressivo de conter a contestação frente inúmeras medidas impopulares já anunciadas. Até que ponto a população vai julgar essas medidas adequadas se o seu desejo é ver resultados imediatos que aliviem os efeitos da crise? De certo, isso depende de um forte apoio midiático, de opositores nas ruas serem tratados como bandidos, de opositores no congresso serem vistos como ladrões ou populistas irresponsáveis, e, principalmente, a população se sentir impotente para contestar.

Enquanto se confundir a opção Temer (opção essa sem nenhuma consulta da população) com a espetacular manipulação midiática sobre a legitimidade do anterior governo Dilma, será mantida uma via reassentada nas "negociações de bastidores". Afinal, é um governo sem base social nem programática a respeito de metas de desenvolvimento30. Tende a se sustentar na capacidade de "empurrar com a barriga" o conflito distributivo no âmbito do orçamento e "feudalizar" o sistema de decisões entre aqueles que garantirem de forma açodada e súbita o respaldo institucional e social a sua condução tecnocrática.

\section{CONCLUSÃO}

\section{A IMPORTÂNCIA DE RECUPERAR 0 TEMPO E 0 ESPAÇO DA GRANDE POLÍTICA}

As perspectivas que se abrem com o golpe de 2016 é a interrupção do processo de transição do neoliberalismo a um Novo Projeto Nacional Brasileiro. Logo, não sugerem outro período para um desenvolvimentismo de direita como no pós-1964. Além disso, o ponto de partida da nova onda conservadora é a inviabilidade de um Estado de Bem Estar Social na profundidade definida em 1988. Afinal, não se projeta uma economia de altas taxas de crescimento e acelerada transformação estrutural positiva pela via de sua rein-

\footnotetext{
${ }_{30}$ Como ilustração, aprofundar o messianismo sobre o pressuposto de que "contrações fiscais" tendem a ser "expansionistas" é desconsiderar que isso não encontra consenso na literatura econômica. Trabalho recente de Gobetti, Orair e Siqueira (2016) apontou evidências que os multiplicadores de alguns gastos públicos são expressivos durante as recessões. Por exemplo, cortes de 1 real em benefícios sociais e investimento público tendem a produzir quedas de 1,50 a 1,70 no PIB
} 
dustrialização para torná-lo possível. Logo, é a constituição federal que deve ser readaptada à mediocridade econômica de um débil padrão de desenvolvimento que será naturalizado como norma, ao invés da recuperação das estruturas de coordenação e planejamento estatais para um Novo Projeto Nacional no qual aquele padrão estivesse apto a satisfazer as aspirações pactuadas socialmente na carta magna.

A compreensão do Lulismo como projeto popular depende da perspectiva de classe. Em termos de Gramsci, o Lulismo marca a possibilidade de uma "revolução passiva", na qual um movimento reformista ia gradualmente abrindo a possibilidade de novas modificações. De fato não deu margem a uma perspectiva revolucionária ativa, mas também não se tratou de mera concessão "pelo alto" de classes dominantes para a satisfação de algumas demandas sociais. Isso fica claro pela reação em prol da restauração das bases fundamentais da dominação de classe no curso de um golpe.

O Lulismo, tendo como resultante a cobrança de mais direitos, evidencia que algo fugiu ao controle das classes dominantes e abria a possibilidade de transformações na ordem social. Uma complexa dialética entre graus de renovação e restauração social explicitou a necessidade de luta por mais direitos ainda que, contraditoriamente, não a organizou em termos político-estratégicos de forma plena. Isso deixou exposta a um impulso de restauração desproporcional quando mal se fundaram as bases iniciais de um Estado de Bem Estar social (e ainda descoladas de uma recuperação efetiva de um Estado Desenvolvimentista).

A gravidade das forças restauradoras só se compreende à medida que se enfatiza sua rejeição a qualquer possibilidade de avançar na renovação da ordem social diante do medo das massas exigirem mais e questionarem os limites da sociedade conservadora.A fim de evitar isso, as forças restauradoras desviam de uma rota que estava pressionando por uma maior radicalização da democracia e recolocam nos trilhos de um "liberalismo de Estado". Assim, deslocam o problema para a recriação do Estado a ponto de transformar reivindicações sociais mais profundas em expressões de irracionalidade diante da necessidade de garantir estabilidade à ordem vigente.

Nesse sentido, como todo golpe, assume um caráter contra-revolucionário que, no caso brasileiro atual, foi por antecipação dado que não havia um projeto nacional consolidado que desse maior sustentação ao projeto popular. Por isso, é importante notar que as forças de restauração observaram o potencial revolucionário antes mesmo das massas se organizarem e reagiram para que nem a possibilidade de aprofundar uma "revolução passiva" fosse tolerada. Essas forças distorcem o sentido de uma lógica reformista re- 
tirando-lhe aspirações progressistas, passando a traduzi-las em franco combate a um suposto estatismo visto como imoral (permissivo à corrupção) e irracional (impede a eficiência econômica). O Estado antes reconhecido como arena de mediação política para garantir conquistas de direitos e proteção social, agora volta a ser visto como um empecilho às virtudes meritocráticas do capitalismo idealizado.

Nesse ínterim, a luta de classes deixa de ser por mais direitos como se desencadeou no Lulismo (mesmo sem organizar politicamente de forma satisfatória), e volta a ser para impedir a perda daqueles direitos já conquistados não só no período recente, mas historicamente sedimentados desde o Varguismo. Assume-se então o caráter duplo de resistência: a luta pela soberania nacional e a luta pelo valor do trabalho. De fato, trata-se de um recuo tático para tentar recompor suas bases sindicais e partidárias diante de uma correlação de forças altamente desfavorável que levou a negação da política. Mas, ao contrário do desejo de facções esquerdistas, não se trata de um contexto para novas utopias sem a noção clara de tempo e espaço.

Qualquer resposta partirá da formulação de ideias com um conteúdo claro de realidade concreta, lidando com as forças condensadas no território abertas para a recomposição das bases de um projeto popular. Não falta rumo estratégico para esse projeto e nem uma ideologia orgânica para ser preciso voltar a um exercício inicial de idealizações puras, o que falta é recuperar sua capacidade de articulação política. Das ocupações estudantis às lutas contra pacotes infames de ajustes das contas estaduais e municipais, a resposta está no território que é a base social para colocar o papel ativo da grande política na "ordem do dia".

\section{REFERÊNCIAS BIBLIOGRÁFICAS}

1. ANDERSON, P.: Crisis in Brazil. London Review of Books. V. 38, n 38. 21 April 2016.

2. BARROSO, L. R. Modelo do Brasil não é capitalismo, é socialismo para ricos. Entrevista ao Estado de São Paulo, 24 de maio de 2016.

3. BRESSER-PEREIRA, L. C. "Do Estado patrimonial ao gerencial”. In: PINHEIRO et al (orgs.). Brasil: um século de transformações. São Paulo Companhia das letras, 2001, pp. 222-259.

4. BRUNO, M. Ortodoxia e Pseudodesenvolvimentismo. Insight Inteligência. Abr-Jun/2015. p. 94-105.

5. COUTINHO, C. N. "A hegemonia da pequena política”. In: OLIVEIRA, F. et al. (org.). Hegemonia às avessas. São Paulo, Boitempo, 2010, pp. 29-43.

6. DANTAS, A. Neoliberalismo e globalização: uma visão crítica ao discurso oficial In: Memória, Representações e Relações Interculturais na América Latina. Nuseg/UERJ, 1998, p. 9-17. 
7. DANTAS, A. Implicações econômicas e desafios das políticas sociais no Brasil. Latinidade, v.5, p.67- 76, 2013.

8. FAORO, R. Os donos do poder: formação do patronato político brasileiro. São Paulo: Globo, 2001.

9. FERREIRA, A. e JAYME JUNIOR, F. Metas de inflação e vulnerabilidade externa no Brasil, Anais da ANPEC, 2005.

10. FREYRE, G. Casa-Grande e Senzala. São Paulo: Global Editora. 2005.

11. FÓRUM 21; FES; SEP; PLATAFORMA POLÍTICA SOCIAL. Austeridade e retrocesso - finanças públicas e política fiscal no Brasil. São Paulo, 2016.

12. FURTADO, C. Não à recessão e ao desemprego. Rio de Janeiro: Paz e Terra, 1983.

13. GOBETT, S.; ORAIR, R..; SIQUEIRA, F. Política Fiscal e Ciclo Econômico: uma análise baseada em multiplicadores do gasto público. Anais do XXI Prêmio do Tesouro Nacional, 2016.

14. HOLANDA, S. B. Raízes do Brasil. São Paulo: Companhia das Letras, 1999.

15. JABBOUR, E.; DANTAS, A.: O presente e o futuro do capitalismo brasileiro em Ignacio Rangel. Artigo no prelo em homenagem à Ignacio Rangel à publicação editada pelo BNDES/ABDE.

16. KRUGER, A. “The Political Economy of the Rent-Seeking Society”. American Economic Review,n.64 (3), pp. 291-303.

17. RANGEL, I. Obras Reunidas. Rio de Janeiro: Contraponto, 2005.

18. REBELO, A.: A chave das maiorias heterogêneas. Princípios. n. 68, Fev/Mar, 2003, pp. 20-21.

19. REQUIÃO, R. Limitações arbitrárias ao gasto público e a corrosão dos vínculos de solidariedade nacional. (Discurso no Senado Federal). Caros Amigos, 17 de setembro de 20016.

20. SERRANO, F.; MELIN, L. E. Political Aspects of Unemployment: Brazil”s Neoliberal U-Turn. Crítica Marxista. Gennaio/Frebbraro, 2016.

21. SINGER, A. “Cutucando onças com varas curtas”. Novos Estudos. 102. Jul/2015. pp. 43-71.

22. SOUZA, J. A tolice da inteligência brasileira. São Paulo: Le Ya, 2015.

23. TEMER, M. Por uma democracia eficiente. Folha de São Paulo, 2 de setembro de 2013, p. 3.

Artigo aceito em 18 de dezembro de 2016. 